at.

405

A213

$1856^{\circ}$

woL.L.

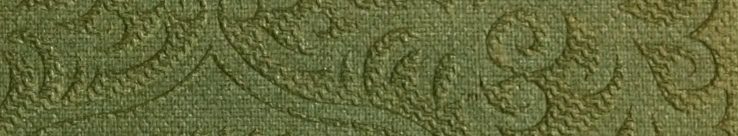

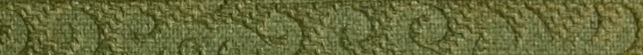

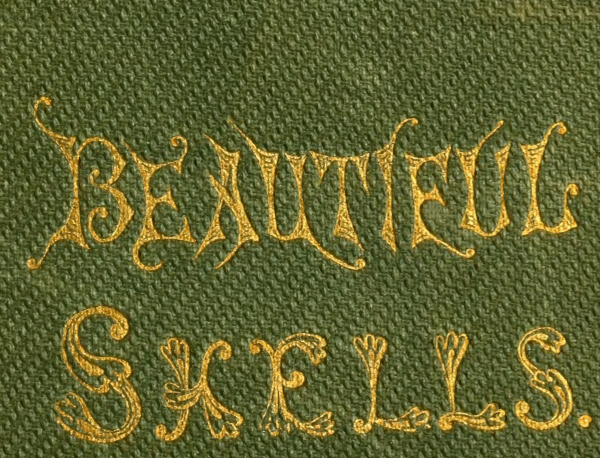
ite (s) $x+941 \%$

(a)

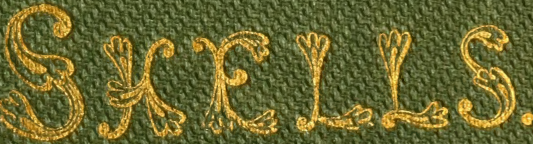


Carced

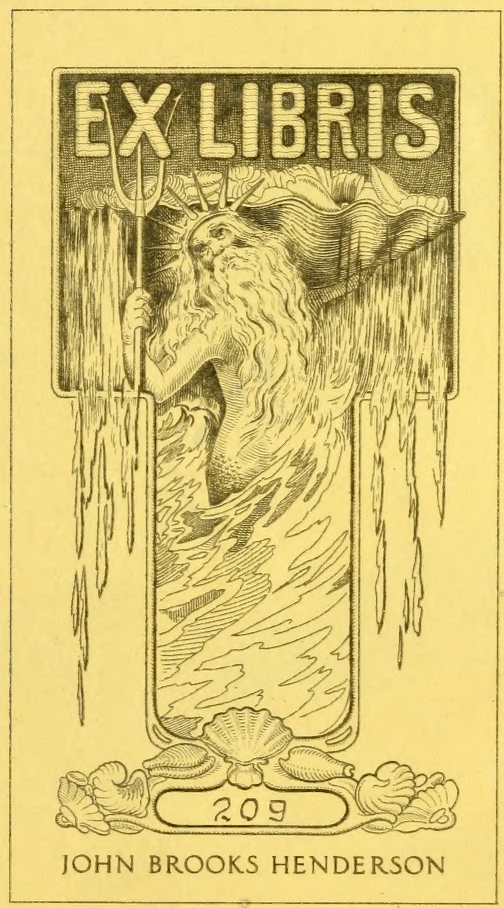

s ADAMS H.G. 


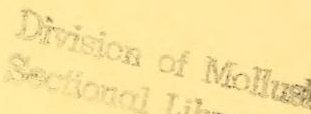





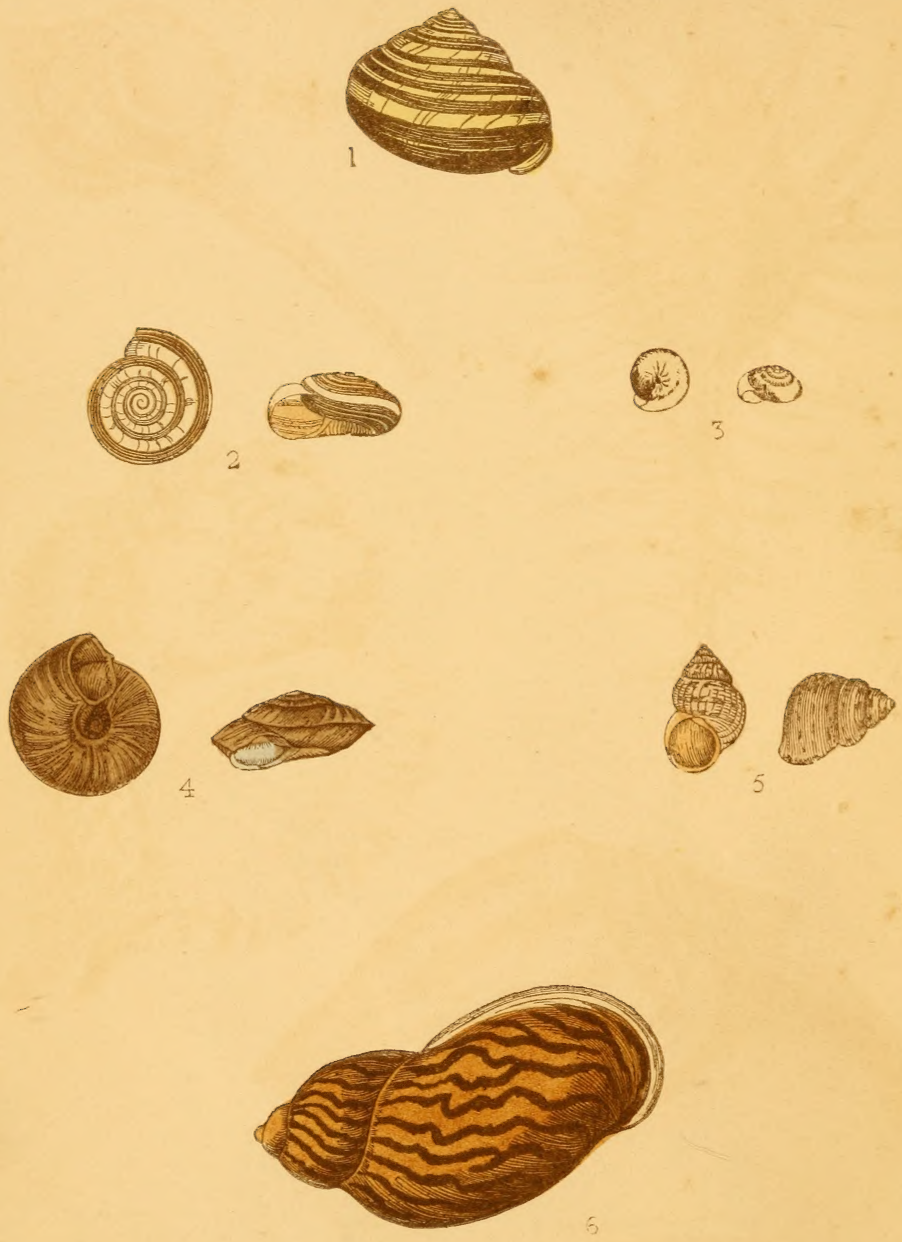

PlateI. 

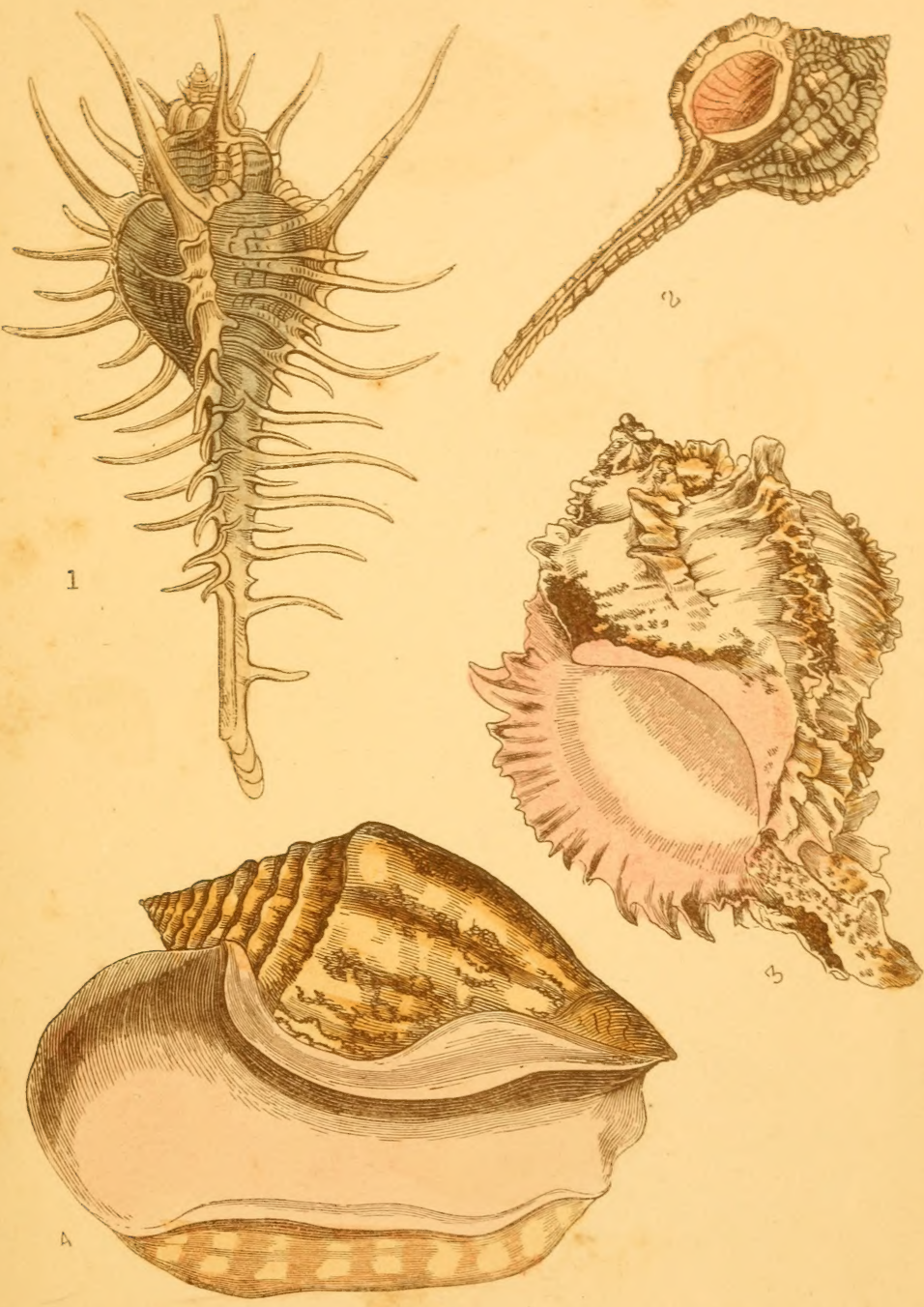

Dhofifons of Miotis 


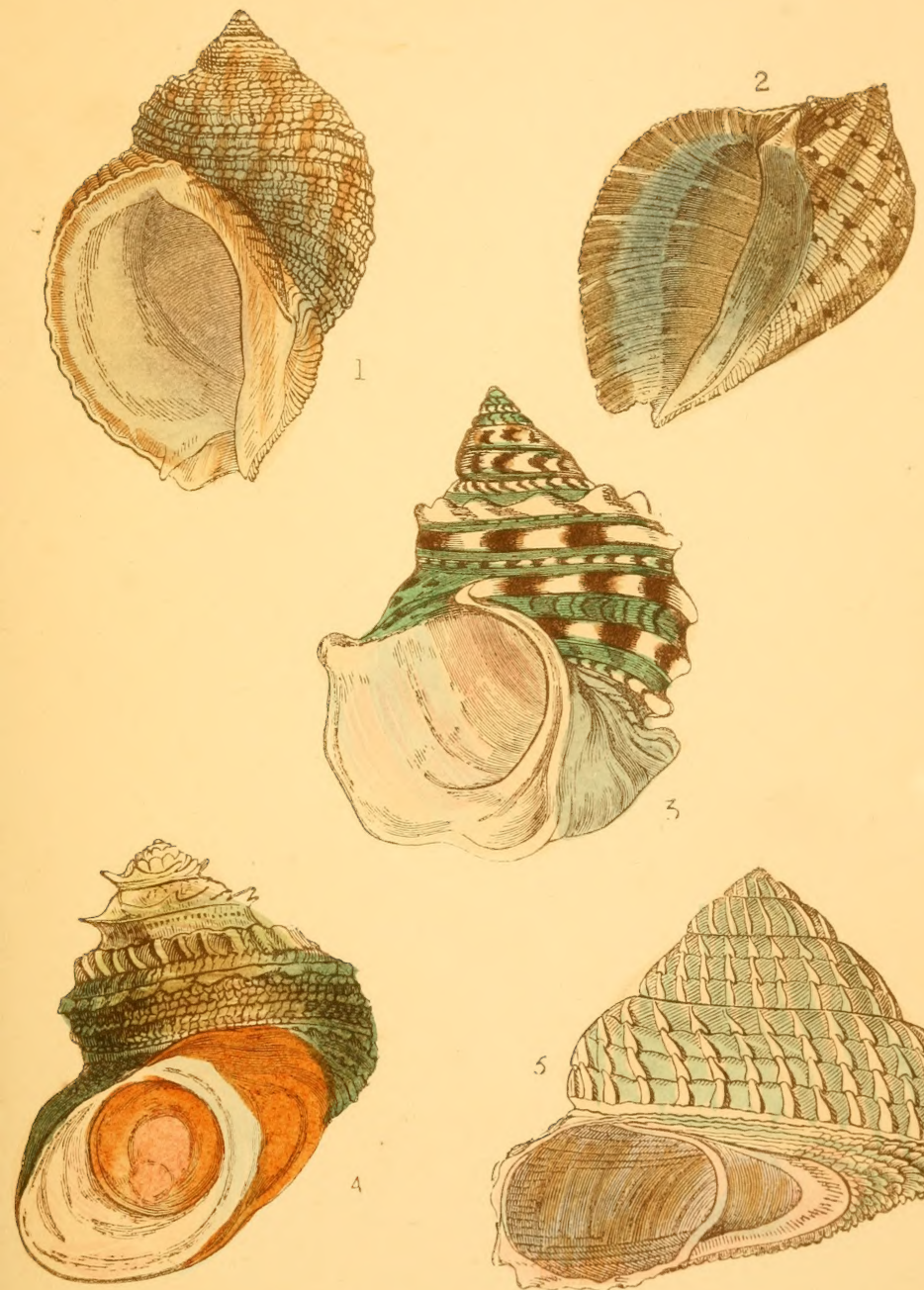


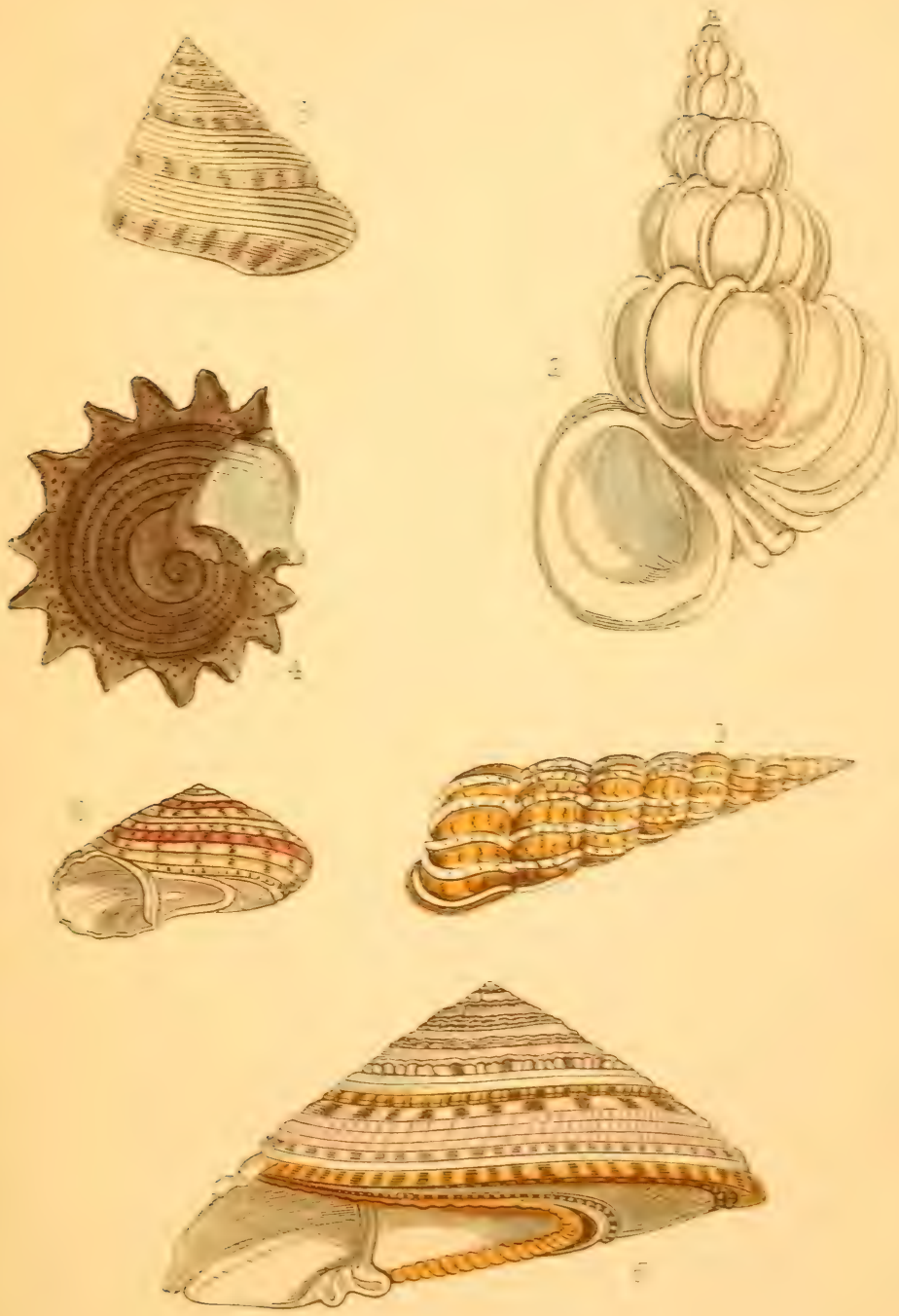


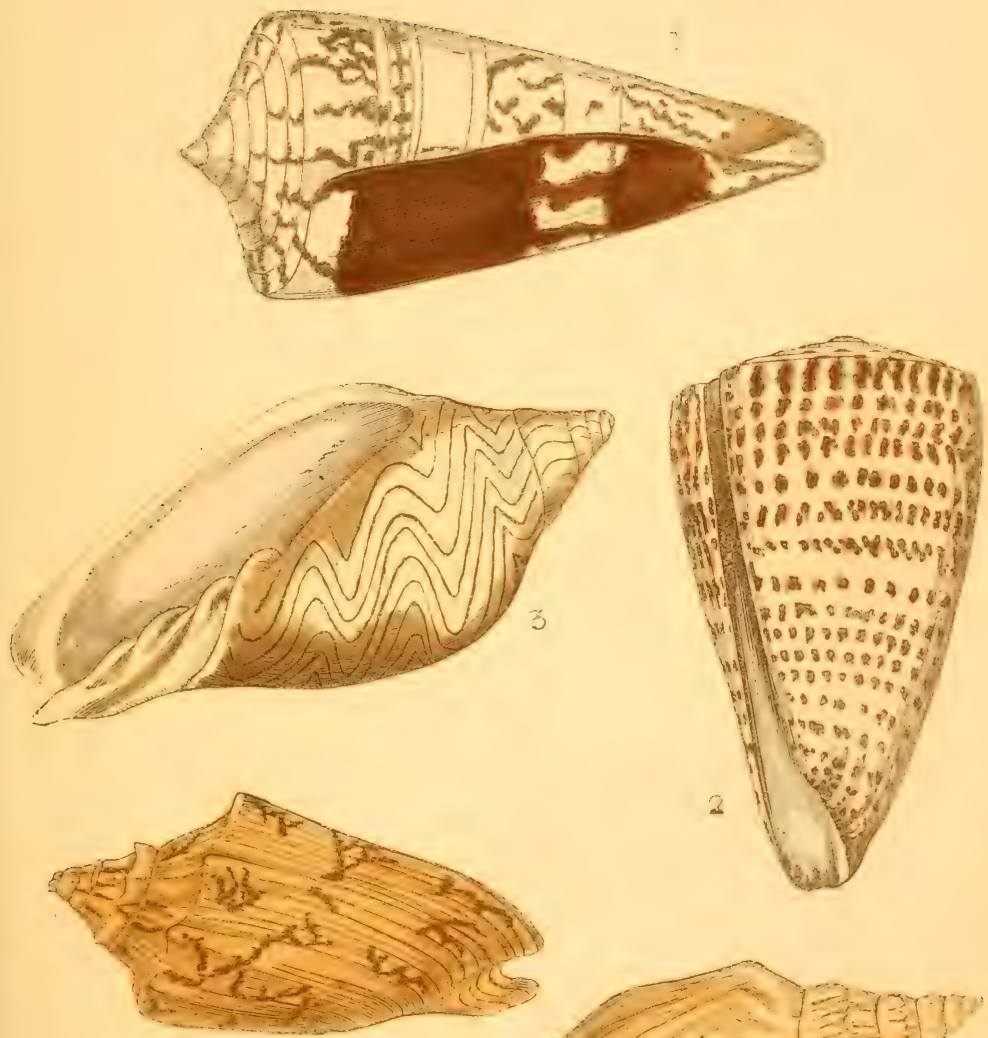


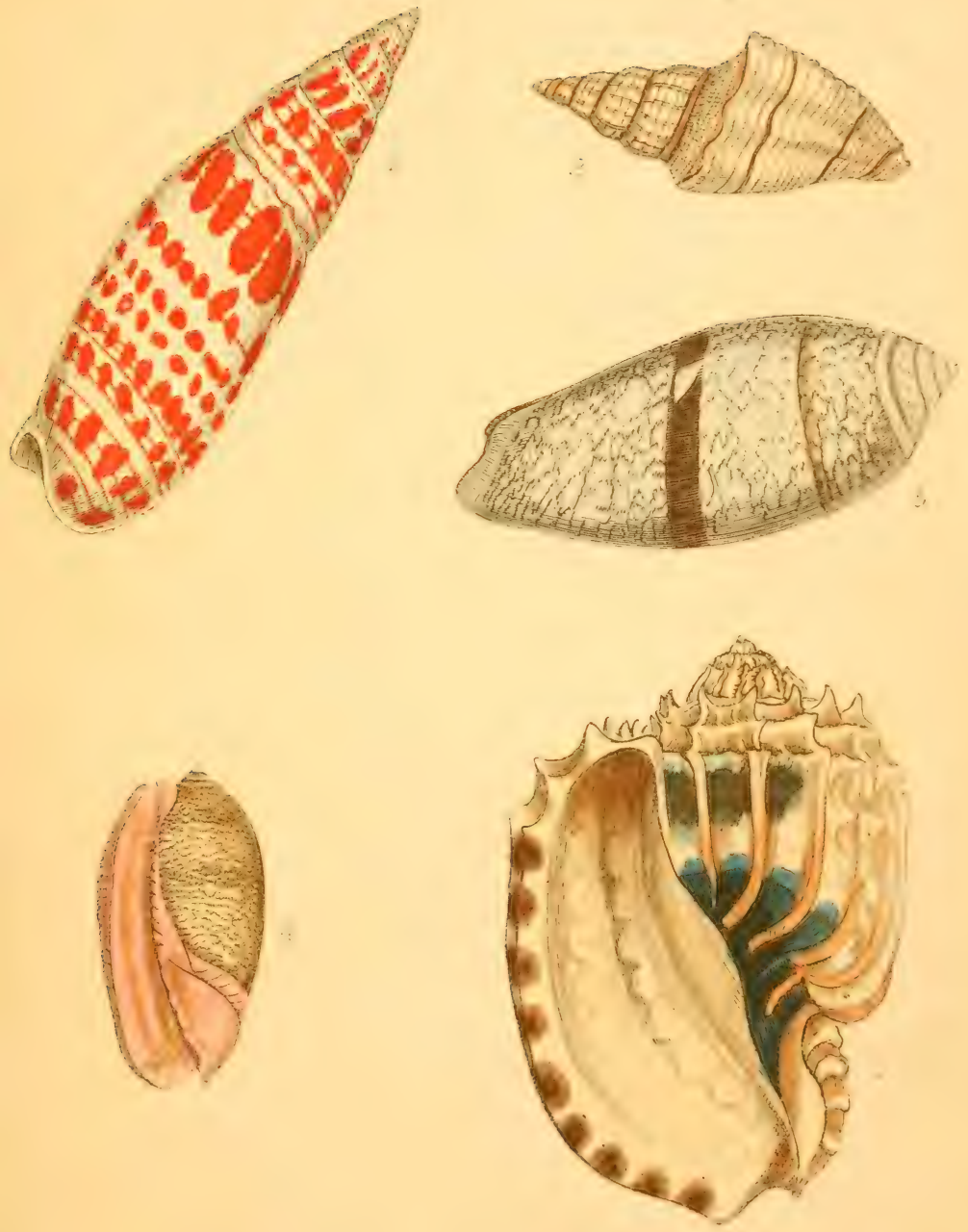


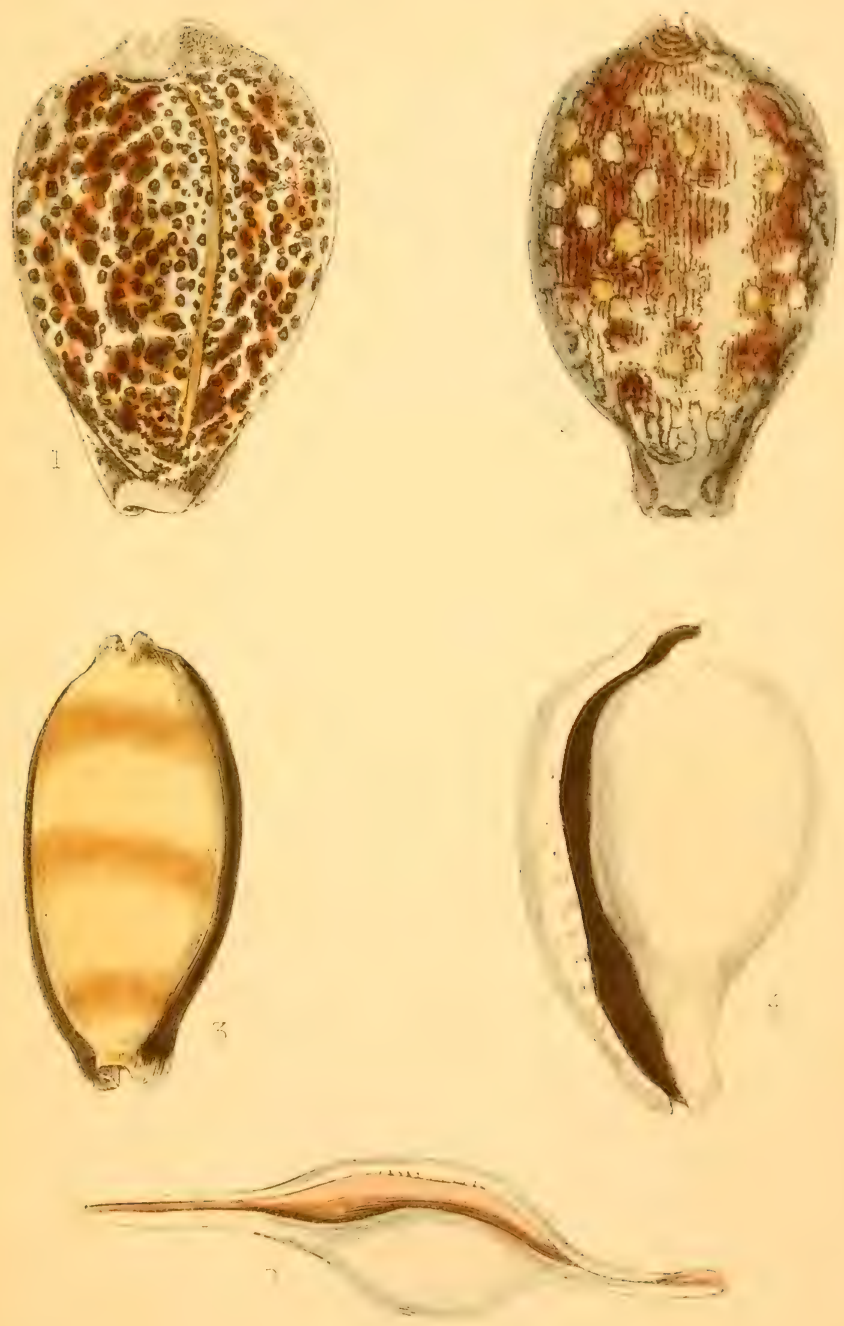




\section{BEAUTIFUL SHELLS:}

TIIEIR NATURE, STRUCTURE, AND USES

FAMILIARLY EXPLAINED;

WITII DIRECTIONS FOR

COLLECTING, CLEANING, AND ARRANGING THEM IN THE CABINET;

DESCRIPTIONS OF

\section{THE MOST REMARKABLE SPECIES,}

AND OF THE CREATURES WHICH INHABIT THEM;

AND EXPLANATIONS OF

THE MEANINGS OF THEIR SCIENTIFIC NAMES.

$$
\triangle N D \text { OF }
$$

THE TERMS USED IN CONCHOLOGY.

$$
\text { B I H. G. A D A M S, }
$$

Aluthe" of "Nests and E'ygs of Familiar British Birds," "Beautiful Butterflies,

"Facourite Song Birds," "A Story of the Seasons," fc. \&c.

ILLTSTATED WIH NCHEROUS ENGRAVINGS \& COLOURED PLATES.

$$
\text { L ON DON: }
$$

GRoumbrHDG AND SONS, 5, PATERNOSTER ROW. 



\section{N'T R O D UCTI ON.}

\section{WHAT ARE SHELLS?}

Dr. JoIrnson gives us no less than eight different meanings for the word SHELL. First, he calls it 'The hard covering of anything; the external erust.' Second, 'The covering of a testaceous or crustaceous animal.' And here we may stop, for this is just the signification which has to do with our subject; so let us turn the sentence inside out, and see what we can make of it. We all know what a covering is-an outer coat, a case, a protection from injury, a husk, a crust, a-in short, a shell,-seyll or scell, as our Saxon forefather's caller it; schale, as the Germans now term it. No Latin nor Greek liere, but the good old Saxon tongue, somewhat rough and rugged, perhaps, but stout and sturdy, and honest and serviceable; a kind of language to stand wear and tear, like a pair of hob-nailed shoes, with little polish, but useful, yes, very useful! Well, we have got so far, now comes a hard word-TES-TA-CE-ous, what can it mean? It is pronounced tes-tashus, comes from the Latin testacens-having a Shell, and means consisting of, or composed of shells; so we find that a testacean is a shell-fish, and testaceology is the science of shells. Johnson's second meaning of the word testaceous is 'Iraving continuous, not jointed shells, opposed to erustaceous.' So we find that some naturalists eall those testaceous fish, "whose strong and thick shells are entire and of a piece, because those which are joined, as the lobsters, are crustaceous."

Now some of the true testacean have shells in more than one or two pieces, and therefore this last explanation of the term is rather calculated to mislead a learner; but we shall explain presently wherein the difference consists between them, and the Crus-TA-CEous, or, as we pronounce it, lirus-ta-shus, fish consists. Here is another long word, it comes fiom the Latin crusta, a word of many meaninigs, all having reference to an outer coat or eovering. Niy readers know all about pie-erust, and have perhaps heard i 
surly, snappish. peevish person called a crusty fellow; they will now understand what is meant by a crustacean and crustaceology, that part of Zoology which treats of crustaceous animals. They constitute quite a large family, these ologies, and have a strange rray of twisting themselves about, and exchanging limbs and features, so that one is puzzled at times to tell which is which. But here we hare fixed two of them, called Testaceologr and Crustaceology, twin brothers, and very much alike in their characteristics. Let us have a good look at them, so that we may linow them again if we should lose sight of them for awhile. Now we will spell over the name of the first-

\section{CONCHOLOGY.}

Why, it is changed already! Has this seience of shells then another name? Yes, and this is it, pronounced leong-kol-o-g.y, and derived from the Latin concha, which means properly a shell-fish with tiro shells, joined by a hinge, as the oyster, the cockle, etc. This present volume then is a work on Conchology, the subject of it is Conchiferous, and whoever studies it will be doing something towards becoming a Conchologist.

So much for urmes and tilles; but still we have the question to answer, What are shells? In a learned work called a Cycloprdia, we find it stated that "shell is the hard calcareous (that is chalky) substance which protects, either partiaily or entirely, the testaceous mollusks exterinally, or supports certain of them internally." Ail this you will understand, except perhaps the word 'mollusks;' this is a term applied to soft-bodied auimals, such as shell-fish, snails, etc., about which we shall hare more to say as we proceed. By this we learn that all shells are not external or outer corerings, some are internal or inner supports for the soft, jelly-like bodies to which they helong, thus performing the duty of bones. An example of this is seen in the shell of the Cuttle Fish, called by naturalists Sepia, a description of which will be found further on in the book.

Shells are either Cirystalline or Granular. Now look at those two words, they almost explain their own meaning. Crystalline shells are those which hare more or less of clearness, transparency as we say, so that if held against the light it shews through them; they are sometimes called Porcellaneous shells, from their resemblance in this respect to porcelain, or chinaware; the Common Corry, (Cyprae Tigris.) is a shell of this description.

Grunulcr, or, as they are sometimes called, Concretionary shells, are the most hard and compact; it is in these that the substance 
called nacre, or mother-of-pearl, is mostly found. One of the commonest examples is the oyster shell; if broken across it will be seen to consist of very thin plates, or lamince, as they are termed, elosely packed together. The thinner these lamina may be the more lustrous and beautiful appears the lining of the shell; that shifting play of colours which we call iridescent, from iristhe rainbow, is then brightest and most noticeable. $\Lambda$ very remarkable substance is this mother-of-pearl; smooth, and shining, and delicately-tinted. Who would expect to find such a beautifu? lining to the rugged, rough, dingy-looking oyster, or mussel shell? Truly these mollusks, some of them, live in gorgeous palaces. And the most curious part of the matter is that from the fluids or juices of their own bodies, and from the chalky matter collected from the water, they are cnabled to secrete or deposit such wonderfuilyronstructed habitations, which after all are little more than chalb. Burn a heap of oyster shells, or any other testaccons coverings, and you get lime the same as that produced by burning the white lumps from the chalk-pit, which lumps, by the way, are said to be composed wholly, or for the most part, of marine shells. This we should call cretaceous matter, from creta, which is the Latin for chalk, or calcerous, from calcis-lime. Granular shells you have been told are sometimes called concrelionary, this is because they contain a large amount of this chalky deposit. The rock called limestone, geologists tell us, is composed entirely of fossil shells and mud, or what was once mud, dried and haraened, most likely by extreme heat, to the consistence of rock. Wonderful this to think of; huge mountains, and mighty masses, and far-stretching strata, forming a large portion of the crust of the earth, made up chiefly of the corerings of fishes, a great portion of them so small as to be scarcely visible to the natied eye-Truly wonderful! But we shall have more to say upon this head when we come to speak of Fossil Shells, as well as on the subject of Pearls, in our chapter on the fish in whose shells they are chiefly found.

It has been a matter of dispute with naturalists whether the testaceous mollusks have shells at all before they issue from the egg, and the main evidence favours the opinion that, generally speaking, they do possess what may be considered as a kind of pattern or model of the habitation which they are to build. This appears to be of a pale horn-colour, and destitute of any markings; but as soon as the animal enters upon an independent state of existence, it begins to assume its distinctive sliape and colour, gradually increasing with the growth of its living tenant, and becoming more and more decidedly marked, until it attains its full perfection of testacean derelopment. Thus the age of some 
shell-fish can be at once determined by the peculiar conformation and markings of the shell.

The relative portions of animal and earthy, or rather chalky matter, which compose these shells, varies considerably in different kinds; in those called Crystalline or Porcellaneous, the animal deposit is much less than in the granular or concretionary shells, where it not only constitutes a large part of the whole substance, hut is more dense, that is thick, and also has the appearance of being membraueous, or organized matter. We can perhaps best explain this by saying that whereas the different chalky layers of the crystalline shell seem merely glued together by the intervening animal fluid; those of the granular shell, as the oyster, appear to be connected by interlacing membranes. But all this my readers will learn more about from more advanced and scientific works if they proceed, as I trust they mill do, in the study of Conchologr, a science which has in a greater or less degree attracted the attention of curious aud contemplative minds in all ages, and the study of which it has been well said is peculiarly adapted to recreate the senses, and insensibly to lead us to the contemplation of the glory of God in ereation.

\section{BEAUTY AND VALUE OF SHELLS.}

In shells, as in all the works of the Almighty Creator, we may observe an infinite variety of form, and if they do not all strike us as alike graceful, yet in each, however plain and simple, there is some peculiar beauty, whether it be the mere hollow cup, or the simple tube, the smooth or twisted cone, the slender spire, the convoluted oval, or half circle, ribbed or spiked, with a lip curving out like the leaf of a water lily, or a narrow rim, like that of a golden chalice; they are indeed elegant, each perfect of its kind, and bearing the impress of a constructive skill far above that of man, who copies from them some of the most graceful and elegant designs wherewith to ornament his buildings, and shapes in which to fashion his articles of luxury or utility.

The most beautiful scroll-work of marble chimuey-pieces, cornices of rooms, and other enriched portions of both public and private structures, are those in which the forms of shells have been taken for the patterns of the artistic designs; and how tasteful and appropriate is the employment of the shells themselves as ornanients for the mantle-piece, side-board, and chiffonniere. Then too,

\footnotetext{
"The rainbow-tinted shell, which lies

Miles deep at bottom of the sea, hath all

Coiours of skies, and flowers, and gems, and plants,"
} 
Not only has it grace and elegance of form, but it has also, richness, and delicacy, and varicty of colouring. In some spercies the tints are intensely vivid as the shifting lights of the amma borealis, or the glowing hues of an autummal sunset; in others pale and delicate as the first indications of coming morn, or the scarcely-perceptible tinge of a just expanding flower-bud; in some the colours are arranged in patterns, regularly disposed; in others, in masses and blotches, of varying shapes and degrees of intensity; in some asain they seem to change and melt one into the other, like the prismatic hues of the rambow. In all, whether distinct and unconnected, or intimately blended, whether regular or irregular, they are beautiful exceedingly. Nor is their beauty of an eranes. cent, that is fading, or vanishing character; unlike plants and animals, which when once dead, are extremely difficult of preservation, Shells, being composed of particles already in natural combination, are almost indestructible; unless exposed to the action of fire, or some powerful acid, they will remain the same for ages, requiring no care or attention, beyond occasionally removing the dust, which would collect upon and defile their pearly whiteness, or obscure the brilliancy of their colours.

So easily collected, arranged, and preserved, and withal so singular and graceful in form, and rich and various of tint, one cannot wonder that Shells have always had a conspicuous place in all museums, and other collections of natural history objects; neither can we feel surprised that a high value should have been set upon rare specimens; as much as a thousand pounds it is said has been given for the first discovered specimen of the Venus Dione; another shell called the Conus cecio nulli, is valued at three hundred pounds; and the Turbo scaloris, if large and perfect, is worth one hundred guineas; while the Cyprece aurantium, or Orange Cowry, if it has not a hole beaten through it, will fetch fifty guineas. It has been calculated that a complete collection of British Conchology is worth its weight in silver.

The following quotation is from "The Young Conchologist," by Miss Roberts;- our readers will do well to peruse it attentively: "We admit that shells are beautiful, and that they are admirably adapted to the exigencies of the wearers; but how shall we account for the endless diversity of shades and colours, varying from the sober coating of the garden snail, to the delicate and glowing tints which are diffused over some of the finer species, in the infinite profusion of undulatious, clouds and spots, bands and reticulated figures, with which these admirable architerts enrich the walls of their beautiful receptacles. The means of producing them must be sought for in the animals themselves. Their necks are furnished with pores replete with colouring fluid, which blends 
insensibly with the calcareous exudation already noticed, and thus recasions that exquisite rariety in their testaceous coverings, which art attempts to emulate, but can never fully equal. Thus far is the result of observation and experiment. It now remains to aceount for the extraordinary fact that the stony exudations of testaceous animals condense only on those parts where they are essential to their welfare. But liere inrestigation ends-the ninieros(c)pe has done its office. It seems as if material nature delighted to baftle the wisdom of her sons, and to say to the proud assertors of the sufficiency of human reason for comprehending the mysteries of reation and of Proridence, 'Thus firr can you go, and no farther; even in the formation of a shell, or its insignificant inhabitant, your arrogant pretensions are completely humbled.

\section{USES OF SHELLS.}

In speaking of shells as ormaments, and ohjects worthy of our study and admiration, we have already mentioned some of their uses, for surely that which contributes to the intellectual improvement and innocent pleasure of mankind. is in its degree useful. But on the more narrow ground of utility, shells may also claim a high place in our estimation. To man in a barbarous and uncivilized state, they furnish the means of performing some of the most important operations of daily life, being extensively used as a substitute for iron. The sarage frequently forms his knife, his hunting spear, and his fish-hook of hard shell. Lister relates that the inhabitants of Nicaragua, in South Amerieil, fasten a shell, called the Ostrea virginici, to a handle of wood, and use it as a spade. In North America the natives use a blue and white belt composed of shells called the Tenus mercenaria, as a symbol of peace and unity, and there too the gorget of the chieftain's war-dress is composed of the pearl-bearing mussel, called by naturalists Vytilus margaritiferus. Many Afriean tribes use the Murex tritonis as a military horn, and a rare rariety of this shell, which has the rolntions reversed, is held sacred, and used only by the priests. Ainong the Friendly Islanders the Orange Cowry is a symbol of the highest dignity. The Honey Cowry, (Cyprea moneta,) forms the current coin of many nations of Africa; and a certain number of these shells strung together, are considered by the slave-hunting chiefs, as an equiralent for so many black-skinned brothers, whom they sell into hopeless bondage.

Among nations, too, in a high state of eivilization, shells are often used for econonical as well as ornamental purposes. To say nothing of mother-of-pearl, wbich is converted into so many articles useful as well as pretty, scallop, or oyster shells, are fre. 
quently employed as scoops by druggists, grocers. and the like; and in the country the dairy-mairl, with the larger kinds of the same shell, skims her milk, and slires her hutfer; whils sometimes by the poor people of both towns and villages, the deeper specimens are converted into oil lamps. One very important use, my young readers will understand, when I speak of a ragesed urchin, who shouts to ever passer-by- 'Please remomber the grotto!'

In ancient times, we are told, the perple of Atliens recorded their votes on public occasions, ly marks upon a shell, thus Pope says-

"Ife whom ungrateful Athens would expel,

At all times just, but when he signed the shell;"

in allusion to this rustrom, of which we are reminded by such English words as Attestation, a certifying, a learing witness; Teslify, to give evidence; Testament, a will, or written disposal of property, etc.; all having their origin, it appears, in the Latin testa-a shell. In ancient poetry we find the word Testudo used to signify a musical instrument, also called a lyre or lute, which instrument, according to tradition, was first made by passing strings, and straining them tightly, over the shell of a tortrise. So the poet Dryden, describing those who listened to the music drawn from this simple invention, says-

\section{"Less than a God they thought there could not dwell, Within the hollow of that shell 'That spoke so sweetly."}

A Greek writer, called Apollodorus, gires this account of the invention of music by the Euyptian god Hermes, more "ommonly known as Mercury. The Yile having orerflowed its hanks, and laid under water the whole country of Egypt, left, when it returned to its usual boundaries, rarious dearl animals on the land; among the rest was a tortoise, the flesh of which being dried and wasted by the sun, nothing remained within the shell except nerres and eartilages, or thin gristly bones; these being shrunk and tightened hy the heat, became sonorous, that is sounding. Against this shell Mercury chanced to strike his foot, and pleased by the sound caused therehy, examined the shell from which it came, and so got a notion, as we say, how he might construct a musical instrument. The first which he made was in the form of a tortoise, and strung with the dried sinews of dead animals, even as are the lutes, harps, and fiddles of the present day. This fanciful mode of accountiug for the origin of music, is thus alluded to by a writer named Brown:- 


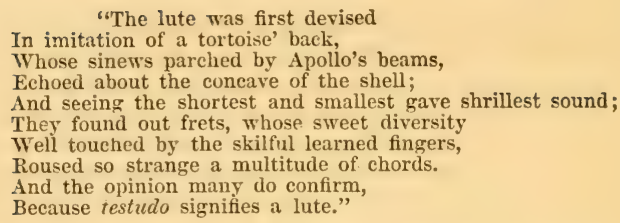

And now we are among the myths and fables of antiquity, we may just mention another application of the shell to musical purposes. Neptune, who, according to the Grecian mythology, was the god of the sea, is frequently represented as going forth in his car in great state and pomp, with a body-guard of Tritons; some of whom go before with twisted conch shells as trumpets, with which we are to suppose they make delightful harmony. Venus, too, the goddess of beauty, rode on the ocean foam in a testaceous car. Thus Dryden says, that Albion-our native land, so called on account of its chalky cliffs, from the Latin alba-white:-

\footnotetext{
"Was to Neptune recommended;

Peace and plenty spread the sails;

Venus in her shell before him,

From the sands in safety bore him."
}

But without believing all these fables, more poetical than true, we may soon convince ourselves that in the hollow chambers of a shell, there does seem to dwell, like an imprisoned spirit, a low sad kind of music. An English poet, named Walter Sarage Lander, has well described this in these lines-

\footnotetext{
"Of pearly hue

Within, and they that lustre have imbibed

In the sun's palace porch, where, when unyoked,

His chariot wheel stands midway in the wave;

Shake one, and it awakens; then apply

Its polished lips to your attentive ear,

And it remembers its august abodes,

And murmurs as the ocean murmurs there."
}

Wordsworth, too, gives a beautiful description of a child applying one of these pearly musical-boxes to his ear,

Many other uses of shells might be mentioned, to show that they perform an important part in the operations of nature, as the means and modes by and in which God sees fit to order the affairs of this world are frequently called; and also promote the ends of science, and the arts of every-day life. By the decomposition of the shells, of which they are partly composed, solid rocks frequently crumble to pieces, and spreading over a considerable 
surface, form a fruitful soil for the nourishment of vegetation. The character of the testaceous deposits, too, enable geologists, as those who study the nature and structure of the earth are termed, to come to important conclusions ou many points connected with the subject of this investigation. And if we include, as the subject of our book allows, the inhabitants of shells, how wide a field of usefuluess opens before us. How many thousands of our industrious population depend wholly, or in part, upon the capture and sale of shell-fish for their support. In some parts, as the western and northern Islands of Scotland, they have in times of scarcity afforded sustenance to the dwellers on the bleak and barren shores, who but for them must have perished. But of all this we shall have more to say when we come to describe the different member's of the testaceous family. We will now offer a few remarks upon

\section{THE INHABITAN'TS OF SHELLS;}

Which belonging to that division of Natural History called the Mollusca, from the Latin Mollis-soft; these Molluscous animals, then, are animals having a soft body, and no internal skeleton. You may be quite sure that a Mollusk will nerer break its bones, because it has none to break; it has a shell, however, which may be broken, at least in some cases, for all Mollushs have not snug habitations of the kind; but wander about the watery or earthy world in which they live, quite naked; such as the sea and land slugs, and some worms, leeches, etc.: but with these we have nothing to do, our present subject including only a part of

\section{MALACOLOGY,}

another member of that queer ology family, deriving its name from two Greek words signifying soft, and a discourse; hence it means a discourse upon soft, or soft-bodied, animals, that is mollusca. It is only a part then of Malacology that we have to do with; that part which relates to the shell-inliabiting mollusks, and strange creatures enough some of these are. We will have a look at them presently; just now it will be sufficient to observe that the mollusca testacea, or soft-bodied animals, furnished with shells, possess the power of exuding, that is, discharging from various parts of their bodies a sticky kind of fluid, which mixing with the chalky matter collected from the water, and becoming hard, forms, in process of time, the shelly covering which is at once a dwelling and a defence for the inhabitant.

Miss Pratt, in her delightful book on "Common Things of the Sea Coast," observes of these shells that, "We gather up those which we find, and looking at their structure would fain know 
something of the inmate of such a dwelling. All nature proclaims the goodness of God. We hear that the bird which wings its way over our heads has a song of joy; the bee hums delightedly by us; and the little shrimp which darts in the clear pool, seems full of merriment. Was the inmate of the shell less cared for by its Maker? No doubt the little builder had some sense of joy, as he framed from his own substance the house which excites our admiration. Doubtless his existence, short and sluggish as it was, had its omn consciousness of pleasure; and obscure as is his history, and little calculated as such a creature might seem to perform an important part in the economy of creation, yet we know that he had a work to do, not only for the living creatures of the sea, but for the well-being of man himself."

\section{CLASSIFICATION OF SHELLS.}

The great naturalist Linnæus divided shells into thirty-six genera, each of which comprised a number of species; of these species somewhere about two thousand five hundred have been described and classified; the varieties, more or less distinct, are almost countless. Of shells found on and about the British Isles, there are about fire hundred and fifty species, or, we should rather say were, for diligent enquirers into this branch of Natural History, are almost daily adding to the number.

We have already seen that shells are sometimes called Crystalline, and sometimes Granular, in accordance with certain peculiarities of construction before mentioned: this is one mode of dirision; there are several others made use of in different systems of arrangement, which only a deeper study of the subject than can be here entered upon, would enable one to understand; the plainest and most common, however, is that which has reference to the form of the shell, which is one of these-

UNIYALVE.

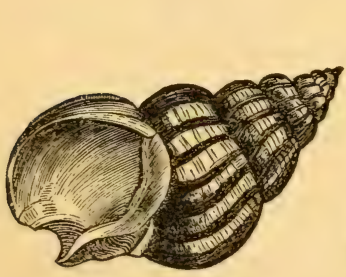

Whell.
BIVALYY.

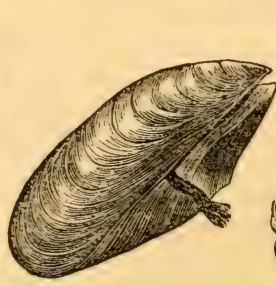

Mussel.
MULTIVALFE.

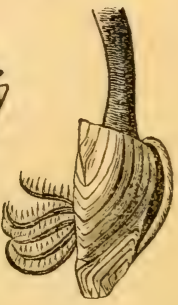

Barnacle. 
These words are derived from the Latin, unus-one, bi-two, multus-many, and therefore it may at once be seen that they apply to shells having one, two, or several pieces or divisions. Talve comes from the Latin valva, and means a folding door, a lid, a piece moving on a hinge, as the divisions in several of these shells do.

This order of arrangement is generally followed by those who make a collection of shells for a cabinet; and to this we shall adhere as at once the most simple and convenient, when we come to describe the several species of testaceous mollusks. We will now say a few words on

\section{TAKING AND PRESERVING SHELLS.}

A diligent searcher along any beach or coast line, will be sure sometimes to light upon curious and valuable specimens, and especially after violent storms may such be sought for, with the greatest chance of suceess, for the agitation of the waters will then have loosened them from their natural beds and dwellingplaces, and cast them on the shore. Very frequently, however, they will be so beaten about and defaced, that they will be comparatively valueless; if enveloped in tang? masses of seaweed, they are likely to be preserved from injury; and such heaps of uprooted marine regetation will often afford a rich harvest to the young conchologist, who should always carefully examine them. Many of the shells are so minute as scarcely to be seen with the naked eye, therefore this search can scarcely be properly effected without the assistance of a pocket lens, the cost of which is but trifling. The undersides of pieces of stranded timber, the bottoms of boats lately returued from a fishing voyage, the fisherman's dredge or net, the cable, and the deep-sea line; all these may prove productive, and should be looked to whenever opportunity offers; nor should the sareh for land and fresh-water shells be neglected, for many of these are very curious, as well as beautiful, and no conchological collection is complete without them. For these, the best hunting grounds are the ditch side and the river bed. the mossy bank and the hedge-row; amid the twining, serpent-like roots of the old thorn and elder trees; the crevices of the garden wall, the undersides of stones, and all sorts of outof-the-way holes, nooks, and corners, where may be found the Striped Zebra, and other prettily-marked suail shells, and many other kinds worthy of a place in-

\section{THE CABINET;}

which may be either large or small, plain or handsome, in accordance 
with the means of the collector. Perhaps for a beginner just a nest of shallow drawers in a deal or other case, may be quite sufficient; these draters should be divided into compartments, on the front side of each of which should be pasted a neatly written label, with the common and scientific name of the species of shell contained in it, together with brief mention of the date when, and the place where, it was taken; and any observations relating to it which can be comprised in a few words, and may seem to the collector of sufficient interest to warrant their insertion. This would be a good beginning; by and by, when the collection is large, the knowledge more ample. and the outlay can be spared, it will be time to think of something ornamental-mahogany and glass, and carved or inloid work, such a Cabinet as mould properly display and enhance the beauties of your testaceous treasures, which are too often stowed away, with other natural curiosities, in a very disorderly, higgledy-piggledy sort of manner, like the collection described by Dryden.

\footnotetext{
"He furnishes his closet first, and fills

The crowded shelves with rarities of shells;

Adds orient pearls, which from the wave he drew,

And all the sparkling stones of various hue."
}

When live shells, as they are called, that is having the living fish in them, are obtained, the lest plan is to place them in spirits of wine, this at once deprives the inhabitant of life, without injuring the shell, which should then be placed in hot water for a time, the body of the mollusk is thus rendered firm, and may be removed by means of some pointed instrument; care should be taken to leave no portion of animal matter within, or after a while it will become putrid and gire out a stain, which will show through and injure the delicate markings of the shell; the surest, most expeditious, and least troublesome mode of cleansing a shell, is to place it in an ant heap for a day or two; the busy little insects will penetrate into its inmost cavities, and remore hence all offending matter. There will be no difficulty in this respect with the multivalve and bivalre kinds, which are only kept closed by means of a set of muscles, which can be tightened or relaxed at the pleasure of the animal within, and become powerless to keep the shell closed as soon as that is dead. Great care must be taken to preserve unbroken the smaller parts of these shells, such as the hinges or tecth, as on the structure of these the scientific arrangement into genera chiefly depends; the beard also, as it is called, an silky threads, must not be removed, as these have much to do in determining the particular species.

River and land shells are generally rery thin and brittle, and must be carefully handled; their colours are not usually so brilliant 
as those of the marine species, but they form links in the testaceous chain, which are necessary to a proper study and elucidation of conchology.

The most glowing and gorgeous of all shells are those brought from the Tropical seas, and, excepting in a few rare instances, specimens of most of these can be obtained at little cost from any dealer, or from sailors returning from a royage. If it is necessary to send either those, or British shells, any distance, or to pack them away in a small compass, the best plan is to wrap them separately in soft paper, place them in a box, and then pour in sawdust, bran, or fine sand, very dry, until all the open spaces are completely filled up.

\section{ON CLEANING AND POLISHING SHELLS.}

All shells, whether inhabited or not, when taken should be soaked for a while in hot water, to remove the dirt which may adhere to them, and dissolve the saline, that is salt, particles contained in the sea water; they should then be thoroughly dried, and if, as is the ease with many, they naturally possess a good polish, they are at once fit for the cabinet. Generally, howerer, it happens that when shells are dry, they lose much of the peculiar brilliancy of hue, which they possess when seen through the medium of the glistening water; to restore this, wash them over with a thin solution of gum arabic, or white of egg; some collectors use a varnish made of gum mastic, dissolved in spirits of wine; this is perhaps preferable, as it is not affected by moisture. Many shells have a very plain, dull, appearance, in consequence of being covered over with a kind of skin called an epidermis, a word derived from the Greek, and signifying the outer skin, sometimes called the cuticle. To remove this, soak the shell in warm water for some time, and then rub it over with a stiff brush until the covering is removed; should this be very thick, it will be necessary to mix a little nitric acid with the water, but this must be done very cautiously, for if too strong it will remove all the lustre from the surface of the shell subjected to its influence. Sometimes the file, and a substance called pumice stone lias to be used, but these are dangerous agents in inexperienced hands. The best polish for the shell after the skin is removed, is a red earth called tripoli, applied on a piece of soft leather.

\section{FOSSIL SHELLS.}

An eminent Geologist, nanced Dr. Mantell, has rery heautifully and poetically termed rocks "The Medals of Creation." As on coins 
and medals we see stamped enduring records of great historical events, so upon the rocks are written by the finger of God, a history of some of the mighty changes which the earth has undergone, and fossil shells are among the plainest and most easily read of the characters or letters, in which these truths are written. As Dr. Harvey, in his "Sea-side Book," observes, "Shelly-coated mollusca have existed in the waters of the sea and in rivers, from a very early period of the world's history, and have left in its most stratified rocks and gravels abundance of their shells preserved in a more perfect manner than the remains of most other animals. Now as the species in the early rocks differ from those found in later formations, quite as much as the latter from the mollusca of our modern seas, the gradual change in the character of the embedded shells marks a certain interval of time in the world's history." So we see that these rocks are the leaves of a great book, written all over with wonderful truths, and those who study such sciences as Geology and Conchology, are enabled to read much that is there written.

Every fossil shell that such a student picks out of the chalk, or limestone, is like a letter in the Alphabet of Creation; it has a significance, or meaning, and a number of such put together, form as it were, words and sentences, that can be made up into chapters, full of instruction, aye, and of amusement too. The study may seem a little dry at first, but never mind, go on, and you will soon be rewarded for your diligence, by the wonders that will unfold themselves to your understanding - the fresh and delightful views which you will obtain into the wide universe, the new and enlarged ideas of the wisdom and goodness of the Creator, and of the formation, habits, and connexion each with each of his various ereatures.

Properly to treat of fossil shells, would require a book of itself, and a large book too; we can here but allude to the subject, as a part, and a very important and interesting part of the study of Conchology; more will be said about it in a volume which we purpose writing for this series, on Rocks, and the petrified organic remains found in and about them.

"Those relics of an older world, which tell Of changes slow or sudden, that have past Orer the fice of nature; fossil shell, Shark's tooth, and bone of megatheran vast, Turned into stone, and so preserved to show liun of those things whereof he ought to know." 


\section{$13 \mathrm{EAUTIFUL}$ SHELLS.}

\section{UNIVALVES.}

G.istriopodi is a name given by some naturalists to a rery extensive group of molliseous animals; the term is derived from two Greek words, signifying stomach and foot;-it hats reference to the kind of fleshy foot which gencrally occupies the whole under side of the body, and by the contraction and exteusion of the muscles of which, the creature is enabled to glide, with a slow but steady motion, from place to place. The Slug and the Snail are the commonest examples which can be adduced of gateropods; and one may tell by their slimy tracks, shining like silver in the morning sunshine, that during the night, which is their principal feeding time, they manage to get over a considerable extent of ground, although "i snail's gallop" is a proverbial expression for slow motion; but it is astonishing how much work of any kind may be done if one "keeps at it;" by doing this the Tortoise beat the Hare, illustrating the truth of the proverb, that "slow and sure wins the race." If you watch a Snail travelling with its house upon its back, it does not seem to make much way, and you are inclined to think that it will be long ere it reaches the new settlement to which it appears journeying with bag and baggage; but leave the spot for a while, and the chances are that on your return, the "slow coach" will

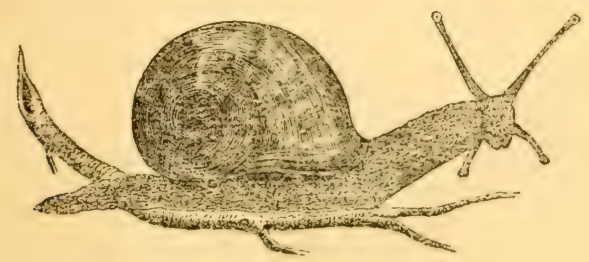

B 
have got somewhere out of sight. Here is a lesson for boys and girls; whaterer you take in hand, don't be in a hurry, and if people say you are "slow," think of the snail, and

This, then, is a shelled mollusk of the third class, called Gasteropoda, according to the system of the French naturalist Cuvier. It has a distinct head, which, like the hinder part of the body, which we may call a tail if we like, projects, when the creature is in motion, considerably from the shell; it is also furnished with what we commonly call horns, naturalists say tentacles, from the Latin tento-trying, or essaying; with these the creature, as it were, feels its way; being extremoly sensitive; they answer the purpose of organs both of sight and touch; put your finger slowly towards one of them, and you will observe that, eren before contact, it begins to retract, or draw in, as though sensible of the approach of some opposing body, as it no doubt is. These horns of the snail, then, are its feelers-ejes to the blind, fingers to the fingerless; so God provides for his creatures all that may be necessary for their existence, and compensates for the deprivation of one sense or organ, by some admirable contrivance which meets the necessities of the case."

\section{THE COMMON. SNAIL}

is called by naturalists Helix aspersa, the generic name being derived from a Greek word signifying spiral, and having reference to the shape of the shell; the plural is Helices, a term applied to all convoluted or twisted shells, which terminate in a point like a church spire: a spiral-shelled fossil is called a helicate. The specific name comes from the Latin asper-a rough, whence also our English word asperity-roughness, and

- It appears likely that the little knobs at the end of the snail's feelers, are, as some nituralists assert, in reality eyes; if so, we were wrong in calling the creature hlind. Yet is their position and construction so different from organs oi sight generally, that they serve rather to streugthen than invalidate the above observations. The number of the horns varies in different kinds of snails from two to six, and some have none at all. These tentacles, when present, ane always situatec abovo the mouth; some of them bare the knobs at the base, others at the sides; and it bias ber'n conjectured that they may be organs of smell, as well as of sight and touch. 
several others. The Helicide, or Melix family, is that which includes the land shell Snails and the naked Slugs, and in this family there are sereral genera; the $y$ are distinguished from the shelled water Snails, both sea and river, by having a different breathing apparatus, and some other points of internal construction which it is not necessary to describe here.

The Common Snail has a mouth, of which it makes good use, as market gardeners well know, and yet this mouth is not furnished with teeth; instead of these, the upper lip, which is of a horny texture, is what is called dentutel, from the Latin deritus - a tooth, that is, divided or scparated, so as to present somewhat the appearance of a row of teeth in the jaw; this lip is of an arched form, and appears to be a rery serviceable kind of instrument to Mr. Heliss aspersa, who, if his character be not aspersed, is very destructive to all sorts of grecnery. The lower lip is divided only in the middle, where there is an opening of some width: it is not horny, like the upper one.

Snails lay eggs, which are about the size of very small peas; they are soft, and of a whitish colour. Being semi, that is, half, transparcnt, or clear, their contents can be partly seen; and in those of a water Suail, deposited against the side of a glass bottle, the young were detected with partially formed shells upon their backs.

To shew how tenacious they are of life, it has been mentioned that Mr. S. Simon, a Dublin merchant, had a collection. of fossils and other curiosities left him by his father; among these were some shells of Snails, and fifteen years after the collection came into his possession, his son had the shells to play with, and placed them in a basin of water, when lo! out came the slimy bodies and knobberl horns of sereral of the Gasteropods, no doubt hungry enough after their long sleep.

We all know that our Common snails hybernate, or sleep through the winter. As soon as the chills of autumn are felt, they seek out some snug crevice in an old wall, or burrow in the earth, or congregate beneath garden pots, roots of trees, thutched roofs, or in any hole or corner that may be consenient, and then throwing a kind of temporary skin, like a drum head, which naturalists call operculum, over the opening of 
their shells, and sticking themselves tist to the sides of their refuge, or to each other, they sleep away, careless of frosts and tempests.

A moist and rather warm stirte of the atmosphere scems most congrnial to the land Snails, some species of which are found in all countries, except those where the most intense cold prevails. Generally speaking, they do not like dry heat, and to escape from it will get under stones, aird into other cool places, from whence a shower brings them forth in such numbers, the smaller species expecially, as to lead to the popular belief that it sometimes rains Snails.

These Gasteropods, although extremely injurious to regetation, must not be regarded as worse than nseless, as they commonly are; besides furnishing food for sererul wild, as well as domesticated, birds, they are no doubt a nourishing article of dict for man. The Romans harl their colitedria, where Snails were regularly fed and fattened for the table; and the French at the present day their escargotoires, or Sintilcry, for the same purpose; some of the Snails so liept, attain an immense size, as well they may if fed, as by the Romans, on new wine and meal. Many poor persons, especially tiose who are consumptive, might no doubt derive much cieap sustenance and bencfit from using the larger species of Helicide, which might be collected from hedges and gardens as food. Why should they not eat those as well as the marine mollusks, such as Oysters, Cockles, Whelks, ete.

Snails have an extraordinary pover of re-producing any part which may be injured or cut off, even to the extent of the whole head, as has been observed to be the case; the reparation of injury done to the sliell they can effect easily, as can all testaceous mollusks. Iiespecting the construction of the shell it may be observed that it is prosuced in the thickness of the mantle, or cloak-like corering which enrelopes the body of the animal; the formation commences at the small end or spire, and gradually goes on, whorl upon whorl, as the still widening eircles which give the ridgy appearance to most univalres, are called. Columella, or pillar, is the name given to the spire on which the cones are rolled; this is sometimes solid, and sometimes hollow; when the latter, the open end is called the Lmbilicus, meaning the narel or centre. 
The opening at the bottom, from which the animal issues, is the last portion finished, and this is called the aperture, a Latin word adopted into the English distionary. Some of these Melices are wide and flat, even hollow and cup-like, with the whorls rising abore the pillar-these are called discoid shells; others which are long and narrow, with projecting spires, are termed turbinated shells; the former being more or less flat or disk-like, the latter twisted, whirling, like a spinning-top, from the Latin turbo-a whirling, a turning round.

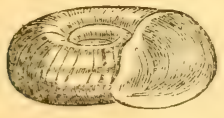

DISCOID.

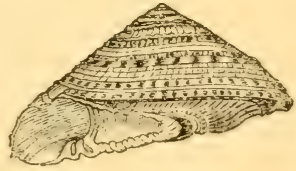

GTIRINATED.

If we take a Common Snail, and plunge it into boiling water, which will instantly kill it, so that it can be removed from the shell, we shall find the whole of that part of the body which was lodged in the upper whorls, or spiral part of the shell, is corered with a thin membrane or skin; this is ealled the mantle, and that portion of it which corresponds with what we may consider as the back of the mollusk, and which is considerably thickened, is termed the collar; here are situated the glands, which secrete the colouring and other matter of which the shell is mainly composed; although the substance called nacre, or mother-of-penrl, is secreted in the thinner part of the mantle; it is however from the collar that the growth or increase of the shell proceeds. It is in accordance with certain variations in the shape and disposition of this mantle and collar, that shells assume such rery different shapes. Sometimes the whorls or spiral ridges, are projected or thrown far out, and this produces the turbinated shell. Sometimes they scarcely rise abore cach other, but rather spread towards the sides, and then we have the discoid shape. Generally speaking, the whorls of a shell take a direction from left to right, but occasionally an ouposite one; 
they are then called sinistral, or left-handed shells: such are not common. If one of the twisted shells be divided lengthways, it will be seen that the inside of the whorls wind in an ascending direction, round the Columella, or central column, as the spiral staireases in the Crystal Palace.

But let us returin to our Garden Snail, who has many near relatives in Britain, several of which have beautifully-marked and convoluted shells, as will be seen by a reference to our coloured illustrations, Plate I. We will introduce them in due order. Fig. 1, the Banded Snail, (Helix nemoralis,) from the Latin nemus-a wood or grove; the prettily-striped shells of this species may be found in great plenty among the roots and in the crevices of the rugged boles of old forest trees, as well as in hedge-rows and in mossy banks, and other situations near woods. Iiig. 2, the Heath Snail, (II. ericetorum,) from erica, the Latin for heath; a small species with brown bands, remarkable for its large umbilicus, perforating the centre of the shell nearly through. Fig. 3, the Silky Snail, ( $H$. sericea,) from the Latin serious-silk-like; the shell of this species is covered with short slimy hairs, which give it a glistening appearance. Fig. 4, the Stone Snail, (H. lapicida,) from the Latin lapis-a stone: Linnæus called the species the Stone Cutter, probably on account of its habit of frequenting stony places, and the peculiar construction of the shell, which has a sharp edge running round each whorl; it is commonly found lodged in the cavities of loose-lying stones, but which it can scarcely be suspected of having hollowed out for its own accommodation.

Fig. 5, the Elegant Cyclostome, (Cyclostoma elegans.) On turning to the dietionary, we find that cyclostomous means having a circular mouth. This species is sometimes called Turbo elegans; the beautifully-marked shells are often found in chalk-hills covered with brushwood. This pretty mollusk has a curious mode of travelling; the under surface of the foot, which is long, is divided by a deep fissure, into two narrow strips, like ribbons; these take hold of whatever the creature may be moving on alternately; one keeping fast hold while the other advances, in like manner to fix itself, and drag the body forward. Fig. 6, the Undulated Plekocheilos, (P. undulatus;) the Latin plecto-to twist or twine, seems 
to be the root from which the generic name of this Snail is derived; the specific name will be easily understood; to undulate, is to flow like wares, and the lines on the shell it will be seen are undulating. This is not a British species, but is introduced here to give variety to the group; it is a West Indian Mollusk, and is found in immense numbers in the forests of St. Tincent; it glues its eggs to the leaves of a plant which holds water, and thus secures for them a damp atmosphere at all times. And here we must conclude our chapter of Land Snails, leaving unnoticed very many beautiful and interesting species, both British and Foreign.

Many poets hare alluded to the Snail, but we can only find room for a few verses by Cowper:-

To grass, or leaf, or fruit, or wall, The snail sticks close. nor fears to fall, As if he grew there, house and all

Together.

Within that house secure he hides, When danger imminent betides

Of storm, or other harm besides, Of weather.

Give but his horns the slightest touch, His self-collecting power is such, He shrinks into his house with much

Displeasure.

Where'er he dwells, he dwells alone, Except himself has chattels none, Well satisfied to be his own

Whole treasure.

Thus hermit-like, his life he leads, Nor partner of his banquet needs, And if he meets one only feeds

The faster.

Who seeks him must be worse than blind, (He and his house are so combin'd,) If, finding it, he fails to find

Its master.

\section{FRESH-WATER SHELLS.}

Many of the following group of Fresh-water Shells, are remarkable for elegance of form, and some for richuess of colouring; 
lence, perhaps, the scientific name applicd to the family in which they are mostly included-Limnaidce, which, like limnto paint, agrees with the French onluminer. These mollusks are found in rivers, streams, ditches, and moist marshy places. Like those which live wholly on land, they breathe through lungs, and therefore cannot exist without air; which accounts for their frequently coming to the surface, when under watcr. In brooks, as well as in stagnant pools, which abound with aquatic plants, they may be found in rast numbers, feeding upon the moist regetation.
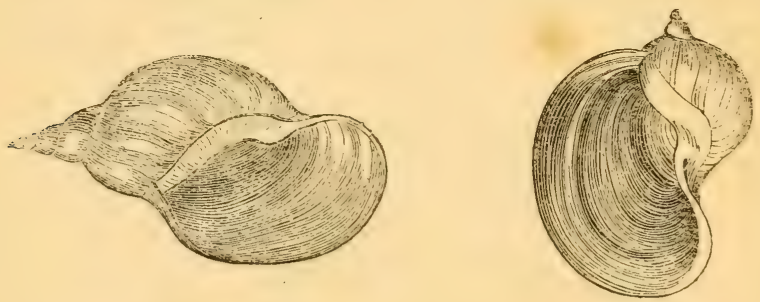

The Common Limnea, (L. stagnatis,) is mostiy an inhabitant of stagnant waters, where it is often seen floating with the shell reversed, as in a boat; this shell, like most of those of the Fresh-water Mollusks, is thin, and easily broken; the shape it will be seen, is peculiarly elegant, the spire being slender and pointed-very different from that of the Spreading Limnea, called by naturaists, $L$. auricularia, from aurusthe ear, to which the broad aperture, or opening of the shell, may be compared; this resembles the other species in its habits.

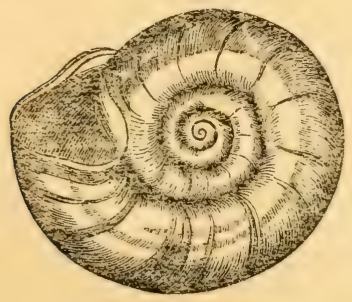
The Horny Planorbis, in Latin $P$. corneus, from cornu-a horn. The shape, you will see, is flat, the whorls rolling upon each other like the folds of a bugle horn; this shape would be termed orbicular, from orbis - a sphere, or circular body. This is the largest European species of Freshwater Shells so constructed; it is 
often found in de'p clear ditches, and yields a beautiful purple dye, which, howerer, soon becomes dull, and changes; it cannot be fixed, and is therefore valucless. The mouth of this shell in fine specimens, is tinged with pale violet or lilac.

There is another kind, the Keeled Planorbis, (P. lurinatus,) which has the outer edge of the shell finely ridged, or keeled; it is very small, and very plentiful in fresh-water, both running and stagnant; where, too, is found the Common Physa, (P. fontinalis, f the latter word meaning a spring or fountain. This little mollusk is a quick and active traveller, it sometimes comes out of its shell, and throws itself about in an extraordinary way, keeping fast hold lyy its foot; the generic name, Physa, would seem to have reference to the round, smooth, delicate shell, and to come from the same root as Physalite, which means a topaz: the members of this genus are very numerous, being found nearly all over the globe. The next

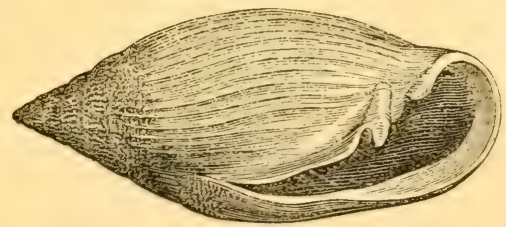

belongs to the family Auriculadce, or Ear Shells. The Midas' Ear, (A. Mide; ) this handsome shell is prized by collectors; it comes from the East Indies. Midas, it is said, was one who set himself up for a judge of music in the old fabulous times, and not appreciating that of Apollo, was rewarded by the angry god with a pair of ass's ears.

The Cone-shaped Melampus, (II. corniformis,) also an Lur Shell, is found in the rivers of the Antilles Islands. It is a pretty shell; the formation is much the same as that of many of the most highly-prized varieties of Marine Shells; of these we shall have to speak presently. Melampodium in Latin, signifies a poisonous plant called Black Helebore; in the Mythology, Melampus was a great magician, who did all sorts of wonderful things; but we cannot tell what relation there exists between either the plant or the magician and this pretty cone 
shell. To give variety to this group, we will now throw in a land species called Megaspira Ruschenbergiana, about the origin of whose name we cannot even hazard a guess; the termination of the generic name, you will see is spira, and

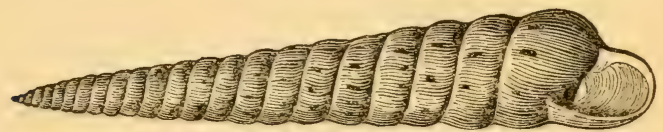

a glance at the shell will at once suggest a reason for this; its long tapering spire consists of twenty-three closely-set gradually increasing whorls. This is a rare shell, whose inhabitant has not yet been described by naturalists; several of the marine species closely resemble it in shape. Much more might be said about the Land and Fresh-water Shells, but we must here leave them, having a wide field before us, namely, the Sea or Marine Testacea, one of the most common of which is

\section{THE , WHELK,}

A univalve shell inhabited by a gasteropod mollusk, or, we should rather say, naturally so tenanted, for very frequently it is taken possession of by the Soldier or Hermit Crab, which having no hard covering to protect their soft plump bodies, are obliged to take lodgings where they can get them, and generally prefer the Whelk shell, of which we here give a figure.

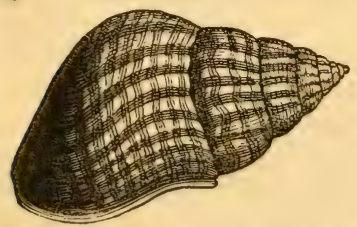

This is one of the commonest of our Marine Mollusks; it is called by naturalists Buccinum undatum; the first, or generic term, being the Latin for a trumpet, and the second, or specific name, meaning waved, or, as we often say, undulated. So we call this the Waved Whelk; fishermen term it the Conch, or the Buckie, and tell strange stories of its ravenous appetite and murderous propensities; how, with its spiny tongue, situated at the end of a long flexible proboscis or 
trunk, it drills a hole in the shell of the Oyster, or other testacean, and sucks out the contents; empty shells, so drilled, are frequently found on the shore, and often, when the dredge is let down into an oyster bed, it comes up time after time filled with Whelks, of which such numbers are sometimes taken, that they are sold to the furmers to be used as manure for the soil. This mollusk is a farourite article of food with the poorer classes of our land, but it is hard and indigestible. The shell may frequently be found in large numbers among the beach stones; it is strong and firm, from three to four inches long, of a dirty yellowish white. There are two other Whelks common upon our coasts-the Stone or Dog Whelk, (B. lapillus,) from the Latin lapis-a stone, and B. reticulatum, so called because the shell is reticulated, or marked with many lines crossing each other, like net-work; it comes from the Latin reticulum - a net; hence also we have reticule - a small work bag, at one time very much carried by ladics.

\section{ROCK SHELLS,}

Are so called on account of their rough and wrinkled forms; they are nearly allied to the Whelks, to which they bear a close resemblance. Several species are found on our shores, the most common being the Humble Murex, (M. despectus,) from the Latin despecto-to despise; this is often used by the fishermen for bait. Some of the foreign Rock Shells are very curious and beautiful; three of them will be found on Plate II.-Figs. 1, 2, and 3. The Common Thorny Woodcock, (MI. tribulus,) from the French for trouble, whence we have also tribulation, which is sometimes said to be a thorny path. This curious shell is also called Venus' Comb. It is found in the Indian Occan, from whence it is also brought. Fig. 2, the Woodcock's Head, (M. haustellum, from the Latin haustus -a draught; the bill of the Woodcock being adapted for sucking. This term is also applied to insects that live by suction. The shell, it will be seen, is destitute of spines, but it is ribbed and beautifully marked. Fig. 3 is worthy of its name 
- the Royal Murex, ( $\boldsymbol{M}$. regius, from regno-to reign. It is a splendid species, of the rich colouring of which, art can give but a faint impression. It is brought from the western coast of Central and South America, where, as well as in the islands of the South Pacific, many new shells of the genus Ifurex have been discovered.

One shell found on our own coast, often mistaken for a Whelk, is the Pelican's-foot Strombus, called in scientific language, Strombus pes-pelicanus, which is but a Latinized form of the English name. This shell varies greatly in shape in different stages of its growth, and by an inesperienced conchologist, the young, middle-aged, and old Strombus, might be taken for distinct species. In the Strombide family, so called we know not why, the same word in Latin meaning a kind of shell-fish, are some species which have produced pearls. One member of the family which we sometimes see in collections, is a large and very beautiful shell; this is the Broadwinged Strombus, - (S. latissimus, ) probably from latesco-to wax or grow broad, or large; issimus being in the superlative degree, would indicate that this shell was very much so, as we find it.is, sometimes measuring as much as twelve inches across. In Plate II, is a representation of this handsome shell, greatly reduced in size, of course: see Fig. 4. We here give a figure, as more curious than beautifu, of the Scorpion

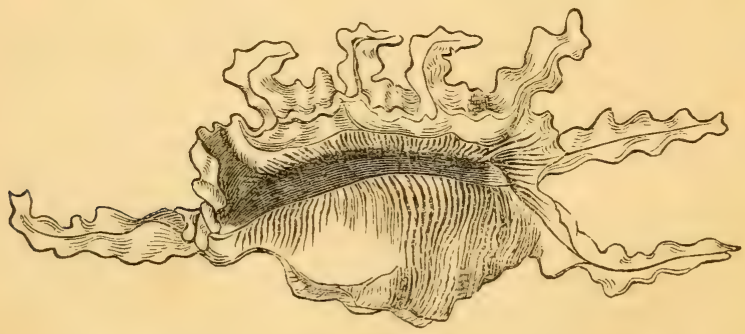

Pteroceras, ( $P$. scorpius, ) which also belongs to the Strombide family; as does the curious Chinese Spindle, (Rostellaria rectirostris.) The generic name of the first of these species, comes from the Greek Ptero, pronounced tero, meaning a wing, 
and cerus-waxen. Botli the generic and specific names of the second refer to the peculiar confurmation of the shell,

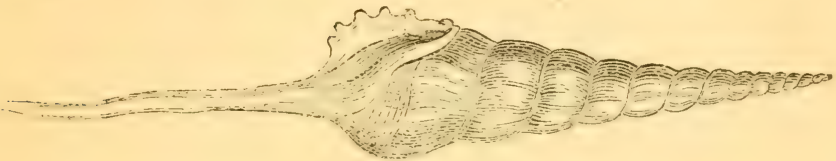

CIIIFSE SPINDLF.

being derived from the Latin, and meaning a straight line or beak.

On Plate III, will be found tle Imbricated Purpurea, ( $P$. imbricata,) Fig. 1, which claims a elose alliance with the Whelks. The generic name has reference to the dye yielded by this, as well as all the sholls of the geruns; the specific name comes from the Latin inorex-the gutter-tile; thus imbricated, a term often used in Niatural History, means ridged, like the roof of a liouse, where the tiles are placed to overiap each other, so that the rain will run of:. The Persian Purpura, or, as it is called in Latin, Purpura Persica, Fig. 2, is another handsome shell of this family group; its name indicates the place where it is found. The other species described comes from Sonth America, and the $P$. lapillus, (the meaning of the specific name has alraady been explained,) is common on our shores, being found in sreat abundance on the rocks at low water. We read in seripture, of Tyrian purple, and there is erery reason to smpose that the rich colom was obtained from these and other shell-fish.

\section{PERIVINIKLE.}

'Tris is the commonest representative which we have of the fimily Turbinile, which comprehends, according to Cuvier, all the species which have the shell completely and regularly turbinated, that is, if we translate the I.atin word into English, twisted. The little Periwinkle, (here le is, is by no means a handsome mollusk, but some of his relatives are very beautiful as we shall presently show.

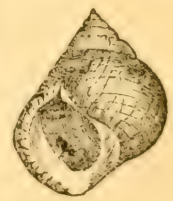


He is called by naturalists T. littoreus, from littoralis-belonging to the shore, and often eaten by boys and girls with great relish; but he is not very digestible, and sometimes occasions dangerous disorders. The Swedish peasants believe that when the Periwinkle crawls high upon the rocks, a storm is brewing from the south; but Linnæus quotes a Norwegian author to shew that according to popular belief, it foretells the approach of a land wind with a calm on shore. Man may learn much of elemental changes from an observation of the movements and habits of all living creatures, which are instructed by God to provide for their safety and wants, and often perceive, long before man himself does, the indications of calm and tempest, rain and drought, etc. But our little Turbo, what of him? will you boil him, and pick out his curled-up form with a pin? or let him go crawling about the rocks, feeding upon the delicate earlier growth of marine vegetation? In the former case, you will have to reject the little kind of horny scale attached to his foot, which forms, when he retires into his habitation, a closely-fitting door to make all snug.

Sereral species of this genus are found on our shores; one of those is the Tiurbo rudis, or Red Turbo, which has a very thick periwinkle-like shell, about three-quarters of an inch long; the colour is dull red, fawn, or drab.

of the foreigu Turbina, sometimes called Turban Shells, we will now introduce two or three species, which will be found on Plate III. Fig. 3 is the Narbled Turbo, (T' marmoratus,) from the Latin marmor-marble; a large handsome shell well known to conchologists, and a native of the Indian seas. Fig. 4 is the Twisted Turbo, (T. torquatus; ) this sholl, when deprived of its outer coat or layer, is beautifully nacreous, or if we may so speak, mother-of-pearly. The specimens which have reached England were brought from King George's Sound. Fig. 5 is called Cook's 'Turbo, (T. Cooliii:) this is a handsome South Sea shell, oftentimes of large size. It has been found in great numbers on the coast of New Zealand.

On Plate IV, we hare placed two very curiously formed and marked shells, called Wentletraps, also belonging to the family Turbinida. The scientific name is Scalaria, from the Latin scala-a ladder, which the ribbed shells are supposed to resemble. Of this genus there are about cighty distinct 
species known; they are mostly deep-sea shells found in warm latitudes, although several inhabit the European seas, and one, the Common False Wentletrap, ( $S$. communis,) Fig. 1, may often be picked up on our own shores. Fig. 2, the Royal Staircase Wentletrap, is a rare and valuable shell, generally brought from India and China; the scientific name is S.prctiosa, given to it by the French Naturalist Lamarck, on account of the high price which it fetched, pretiose, in Latin, meaning costly, valuable. As much as $£ 100$ have been giren for a single specimen of this shell; and a fine one, especially if it exceed two inches in length, yet commands a considerable sum, although not nearly so much as that. A good deal like the False Wentletrap in general outline, is the Awl-shaped Turritella, found in the African and Indian Seas. This is the T. terebra of naturalists; the first name referring to the turret shape common to the genus, and the last being the Latin word for an auger, or piercer. The Roseate Turritella, ( $T$. rosea,) is also sometimes seen in collections; the beautiful rosy tint of the live shell changes to a dull red or brown, on the death of the mollusk.

\section{TROCHUS, OR TOP-SHELL.}

"OF the shelled Mollusca which the dredge ever and anon brings up," says Mr. Gosse, in his delightful volume on the Aquarium, or Aqua-vivarium, as the glass tank in which living marine animals and vegetables are kept, is called, from the Latin aqua-water, and viro-to live, "the Trochi are among the most conspicuous for beauty. The chief glory of this genus is the richly-painted internal surface of their shells, in which they are not excellcd by any even of the true margaritiferous or pearly bivalves."

Of this Trochide family, a few of the members must be introduced to our readers; it is rather a numerous one; consisting of more than one hundred species, which are scattered nearly all over the world, few seas being without some of them. They are found at various depths, from near the surface to forty-five fathoms down, creeping on rocks, sand, masses of sea-weed, etc. We will first speak of those found on our 
own shores, the two commonest, as well as the smallest of which, are the Grey and the Spotted Trochi, scientifically named $T$. cincrarius and $T$. nuculate, the translation of the first Latin specific name being ashy or ash-coloured, and that of the second, spotted. Trochus, in the same language signifies a top, and has reference to the shape of most of these shells, which are something like a boy's whip-top.

Children on the coast sometimes call the last-named of the above species Pepper-and-salt Shelis, beanse in colour they resemble the cloth so named. The Huddy-red Trochus, ( $\mathcal{T}$. ziziplimus,) so callerl, perlaps, becanse in colour it resembles the ziziphia, or fruit of the jujube tree, is also common with us. 'This shell is about an inch long, of a grey tint dashed with dark spots, these follow the line of the spiral turnings, which are very regular, proceeding from the enening below to the apex or point. Scen on shore, its colours are dull and faint, but beneath the water, inhabited by a living mollusk, it looks as though made of pearl, and studded with rubies; the animal, too, is richly coloured, being yellow with black stripes.-See Plate IV, Fig. 3.

Not so common as the last is another British mollusk of this genus, called the Granulated Trochus, ( $T$. granulatus.) It is the larger, and, as many think, the more elegant shell of the two, being in colour, a faint flesh tint or yellowish white, shaded here and there with purple; the spiral lines which encircle it are composed of small round knobs which stand out like beads.

There is a singular shell of this genus, ealled the Carrier Trochus, $(\pi ;$ phorus; $)$ it is generally found loaded with foreign objects, such as shells, smail stones, bits of coral, etc., which it attaches to itself, and so goes about like a collector of natural curiosities, with his cabinet on his back.

The Imperial Trochus, (T. imperialis, ) Fig. 4, whose scientific name explains itself, is one of the handsomest shells of the genus; it is very rare, and has hitherto been found only at New Zealand. Let us gire our young readers a specimen of the way in which scientific writers describe shells; thus, this forcign Trochus, they tell us is "orbicularly conical, the apex obtuse, the whorls turgidly conrex, squamoso radiate at the margin." This is quite a simple affair to some descriptions, 
and simple in fact it is to one, who, by attentive study, has become familiarized with the meaning of the terms. To one also who is acquainted with the Greek and Latin tongues, they will be sufficiently plain, although he has never seen them applied before, for they are all derived from those dead languages, as they are called, and so convey their own meaning to every educated naturalist, no matter of what nation he inay be; and hence their chief value. It is not necessary for our reader's to trouble themselves about the meaning of such terms at present; by and by it will be necessary for them to do so, if they wish to prosecute the study of any natural science.

But about the Imperial Trochus, with its "orbicularly conical" shell-that term we may explain as round and conelike; a reference to Fig. 4, Plate IV, will shew what is meant by this more clearly than words can, and likewise exhibit the beautiful markings of this species, with its ground tint of rich violet brown. Whis beauty is often obscured by calcarious incrustations, and marine plants, shewing that the mollusk is sluggish in its habits-a slothful creature. So it is with human beings, sloth covers and hides the good qualities and virtues with an overgrowth at all times difficult to remove, and oftentimes destructive of all that is fair and good in the character.-Children, be not slothful! The Obelisk 'Trochus, ( $T$. obeliscus,) is a rare white and green shell, sometimes seen in collections; it is of 'a conico-pyramidal form, not remarkable for beauty, and is a native of the Indian seas.

Mr. Gosse speaks of the Tops and Winkles as among the most useful inhabitants of the Aquarium; they mow down with their rasping tongues the thick growth. of Conferce which would otherwise spread like a green curtain over the glass walls of the tank, and obstruet the view of its inhabitunts. Here is this author's description of the beautiful piece of mechanism by which this work is eitected:- "The appearance and position of the organ would surpirise any one who scarehed for it for the first time, and as it is easily found, and as Periwinkles are no rarities, let me commend it to your examination. The easiest mode of extracting it, supposing you are looking for it alone, is to slit the thick nuzzle between the two tentacles, when the point of a recdle will catch and draw out what looks like a slender white thread, two inches 
or more in length, one end of which is attached to the throat, and the other, which is free, you will see coiled in a beautiful spiral manner, within the cavity of the stomach.

By allowing this tiny thread to stretch itself on a plate of glass, which is easily done by putting a drop of water on it first, which may then be drained off and dried, you will find that it is in reality an excessively delicate ribbon, of transparent cartilaginous substance or membrane, on which are set spinous teeth of glassy texture and brilliancy. They are perfectly regular, and arranged in three rows, of which the middle ones are three-pointed, while on each of the outer rows a three-pointed tooth alternates with a larger curred one, somewhat boat-like in form. All the teeth project from the surface of the tongue on hooked curves, and all point in the same direction."

And with this curions piece of mechanism the little Winkle works away and cuts down swathe after swathe of the minute regetation, just as a mower does the meadow grass; only the mollusk eats as he goes, and so gets payment for his labour; the man has it in another and to him more useful form. We might tell a very long story about these Tops and Winkles, which are nearly related to each other, but must now pass on to describe the rest of the shells on Plate IV, which are the Perspective Solarium, (S. perspectivum,) Fig. 5, the generic name comes from sol-the sun, and vierred perspectively, that is, in such a position that the whole top of the shell is at once presented to the view, looking like a flat surface, it presents a circular appearance, marked with rings and rays like representations of the sun sometimes do.

The Variegated Solarium, (S. variegatum,) Fig. 6, is a small but very pretty shell, somewhat rare. The mollusk is remarkable on account of the singular shape of its operculum, which differs from that of all other species; it is of a cone-shape, and corered from top to bottom with what are called membranous limellæ, that appear to stand out like little shelres winding up spirally. This singular form of operculum has been long known to naturalists, but it is not until lately that they have discovered to what species of testacean it belonged. Let us here explain that operculus is the Latin for a cover or lid. 


\section{CONES, VOLUTES, MITRES, AND OLIVES.}

THese are names given by collectors to certain classes of univalve shells distinguished by peculiarities of formation, more or less distinct. We shall describe two or three of each, that our readers may have some idea of the meaning of the terms which are often used by those who speak or write on conchology.

The family of Cones, called Conida, is an extensive one, considerably above two hundred species having been discovered. Many of them are very beautiful both in shape and colour, so that they are highly valued by collectors; they are principally found in the southern and tropical seas, upon sandy bottoms, at depths varying from a few feet to serenteen fathoms. The shells are generally thick and solid, rolled up, as it were, into a conical form; the most familiar illustration that can be given of this form is a sugar-loaf, which all these shells more or less resemble in general outline, as thus-
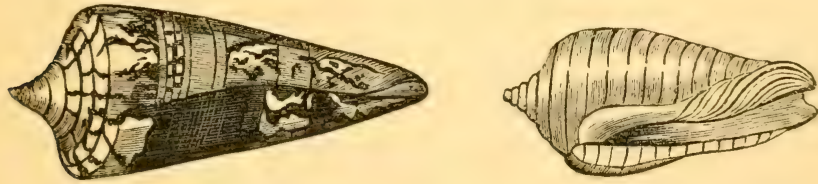

Cone's are either plain or coronated, that is, crowned, having rows of projections round the top of the shell, like the second of the above figures; and this forms a mark of division into two classes, although these classes often run, as it were, one into the other; some plain cones having slight irregularities of surface, and some crowned ones being very nearly plain.

The Common, or Ordinary Cone, (Conus generalis,) Plate V. Fig. 1, is an elegantly-shaped and beautifully-marked shell, having much the appearance of being carved out of some rare kind of marble. The Lettered Cone, (Come littoralis,) Fig. 2, appears to be scribbled over with Hebrew, Greck, or Arabic characters, and almost crery species has something peculiar in its markings; elouds and reins, and dots, and stripes, and hands, of every conceivable shape and mode of arrangement, 
may be met with in these shells, whose surface, when the epidermis, or outer skin is removed, bears a beautiful polish. Curious names have been given to some of them, such, for instance, as the High Admiral, Vice Admiral, and Guinea Admiral, which indicate the rank they hold in the estimation of collectors. From five to twenty guineas is the price at which good and rare ones have been valued, and one, the Conus cedo mulli, which may be translated, the Cone second to none, has fetched the enormous sum of three hundred guineas. It must not be supposed that these shells exhibit all their beauties when, inhabited by a carnivorous, or flesh-eating mollusk, they move slowly about, or lie for a time motionless among the rocks and sand-beds of the ocean. The beforementioned epidermis, which is the Latin for the outer skin of the human body, corers them like a cloak or mantle, which is the name it bears among naturalists. Much careful labour is required to bring them to a fit state for cabinet shells.

Voldtes form an extensice fumily of shells under the name Tolutince. The greater part are natives of tropical seas, and dwell far down so that they are seldom found on the coast, except after storms. There are a few European species, but these are not remarkable for beauty, as most of the others are. The generic name signifies twisted, or rather wreathed, as flowers or leaves might be, about some central object. In these shells the spire is generally short, as it is in many eones, sometimes scarcely apparent; the form is usually clegant, and the markings often striking and handsome. On Plate $\mathrm{V}$, will be found three examples-Fig. 3 is the Undulated Tolute, ( $V$. undulata,) the Latin for a little ware is undula, and these marks are like the lines caused by the flowing of the waves on a sandy shore: this shell is found chiefly in the South Pacific; the animal which inhabits it is prettily-marked with zebra-like stripes. Fig. 4 is called the Pacific Volute, ( $\boldsymbol{V}$. Pacificus;) the shape, it will be scen, is somewhat different, being more angular, and it is without the wared lines. Fig. 5 , the Bat Volute, ( $V$.vespertilio, ) is more decidedly knobbed or spiked, approaching nearly to the shape of some of the coronated ones. This species is found in the Indian seas; the specific name is the Latin for a bat. 
Mrtres; these are usually considered as a genus, or branch of the Volute family; the scientific name is mitra, the form is generally long, slender, and pointed-something like the bishop's mitre, hence the common name of the genus. In the Episcopal Mitre, (M. episcopalis,) Plate VI, Fig. 1, we see this form in its greatest perfection; this is a handsome shell found in the Indian seas, and on the coasts of the South Sea Islands. The mollusk is remarkable for a long proboscis, double the length of the shell, the extremity of which swells into a club form, and has an oval orifice or opening: the specific name episcopalis, comes from the Latin, and means of, or like a bishop. The Tanned Mitre, (M. adusta,) from the Latin adustus-burned or parched, is, what is called fusiform and turretted, that is, shaped like a spindle, and haring a spire or turret-like termination. The streaks of colour are transverse, that is, rumning the length of the shell, or in other words, they are longitudinal; this, too, comes from the South Sea Islands. Fig. 2 is the Wrinkled Mitre, (M. corrugata,) from the Latin corrugo-to wrinkle; it is very different both in shape and markings, from the last species; the whorls, it will be seen, are angulated or pointed abore, and the lower part of the shell is much larger than the spiral or upper portion. It is a true mitre nevertheless, although not just such a one as a bishop would like to wear. It inhabits the Indian Ocean, the coast of New Guinea, etc.

OLires; these, for richness of colour and brilliancy of effect, will bear comparison with any genus of shells. Naturalists speak of them collectively as Olivine; they belong to the Volute family, and are said to number about eighty species. Most of those which have reached this country, hare come from the Mauritius, where they eatch them with lines baited with portions of Cuttle-fish. We have here depicted two of them, namely, the Figured Olive, Fig. 3, (Olixa textilina,) from the Latin textilus, which is woren or plaited; and the Ruddy Olive, Fig. 4, (O. sanguinolenta,) from sanquis-blood.

We must now bring our notice of the linivalves to a conclusion; there are several genera, and many very curious and beautiful species which we have been unable to notice at all, and of those which we have, a short account only could be giren; sufficient however, as we trust, to interest our readers 
in the subject, and induce them to continue the study of it into larger works. Before leaving this division of shells, we would call their attention to one of its greatest ornaments, that is the Ventricose Harp Shell, (Harpa ventricosa,) from the Latin ventriculus-the stomach, applied to this shell on account of its swelled or inflated shape. Nothing, howerer, can be more elegant than the whole form, nor more beautiful than the markings of this lorely species, (see Plate VI, Fig. 5,) which belongs properly to the Whelk family.

\section{COWRIES.}

Of Cowries we have already spoken in our chapter on the Uses of Shells, they are among the commonest of our testaceous ornaments, and are remarkable, especially the foreign kinds, for richness and diversity of colour, and the high polish which they bear. The native species are small plain shells, commonly called Pigs, from some real or fancicd resemblance which they bear to the swine; they are pretty little white-ribbed shells, and are tolerably plentiful on various parts of the British coasts. There are three kinds, namely, the Louse Pig, or Nun Cowry, the Flesh-coloured, and European Pig Cowries. The first of these is of a pale reddish colour, with six square black spots on the back; the second is a beautiful rose tint; and the third is ash-coloured or pinkish, with three black dots, and a white streak down the back. The Money Cowry, (Cypraa moneta,) used as current coin in many parts of India, as well as on the coast of Guinea, is a jellow and white shell, with a single band of the former colour; it is small of size, and is sometimes called the Trussed Chicken, for the same reason as the term Pigs is applied to its British relatives. These Cowries are obtained prineipally about the Phillippine lslands, the Maldive Islands, and the coast of Congo, where, after high tides, the women collect them in baskets mixed with sand, from which they are afterwards separated and cleaned, when they are ready for the market.

They are only useful as coin so long as they remain unbroken. The value of a single shell is rery small, as the 
following table will shew:-Four Cowries make one gunder; twenty Gunders one punn; four Punns one anna; four Annas one cahaun; and four Cahauns one rupee. The value of the latter coin is equal to two shillings and threepence, English money, and this would be exchangeable for five thousand one hundred and twenty Cowries; so that it would nerer do to pay large sums in this kind of coin: a waggon would be required to convey a few pounds with. In this country the Moncy Cowries are frequently used as markers or counters in social games; they are generally white, in shape rather broad and flat, being much spread out round the edges, which are slightly puckered, like frills. Here are two figures of the shell, exhibiting the back and front riew.
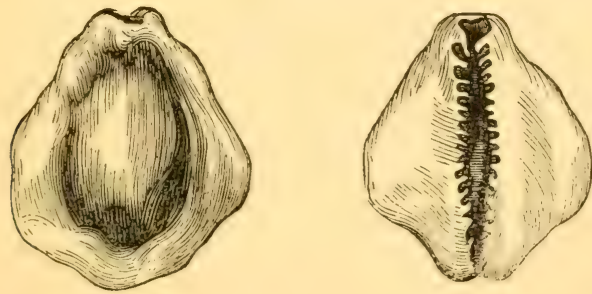

On Plate VII, will be found a group of other Foreign Cowries, most of which will be recognized as familiar ornaments of the mantel and sideboard. Fig. 1 is the Spotted or Leopard Cowry, sometimes also called the Tiger Cowry, (C. tigris,) which, in the earlier stages of its growth, is simply marked with broad bands of lighter colour across the shell. Fig. 2, the Map Cowry, (C. mappa,) curiously marked and shaded, so as to resemble a coloured map; there are sercral varieties of this beautiful shell, such as the rosy and dark varicty from the Pearl Islands, in the Indian Ocean; the Citron and Dwarf Richmouthed variety, from the Mauritius. Fig. 3, the Mole Cowry, (C. talpa,) the last word being the Latin for a mole, is of a more slender form than most other species of the Cypreidee family, so called on account of their beauty, C'yprea being a name of Venus, the goddess of beauty. Any one who has seen a mole, must be struck with the resemblance of its general 
outline to this shell, of which there is a darker-coloured rariety of somewhat stouter form, called exustus-burned or scorched. Of the Poached-egr Comries there are sereral species, the most common is called by naturalists Orulum orum, Fig. 4, from ovum-an egg; the back of this shell is much elevated and rounded; it is smooth and white; the inside is orange brown. Some of the Poached-egg group are of a more slender and angular shape, as, for instance, that called the Gibbons, (1). Gibbosa;) the moon when more than half-full, is called gibbous, that is rounded unequally, as this shell.

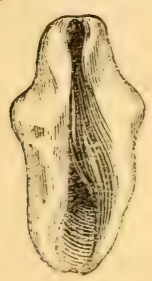

Few shells undergo greater changes, both of shape and colour, during the process of growth, than the Cowries, which are called in France Porcelaines, on account of their high polish and brilliant hues; a single species in different stages of derelopment, might well be, and often is, taken for distinct shells. Much might be said about the Mollusks which inhabit them, but our present subject has rather to $d_{\rho}$ with their onter covering than their internal structure. The most rare and valuahle, if not the most beantiful of these Cowries, is the $C$. aurora, or andantium, Morning-dawn, or Orange Cowrs, a perfect specimen of which has been sold for fifty guincas. There is a rery curious shell called the Common Weaver's Slunttle, (Oculum volva,) menerally included in the (yprea family; of this a representation will be found on Plate YII, Fig. 5. This is brought from China. 


\section{B I V A L E S .}

Acepringots Mfoldusiss, with Bivalve Shells, is the name given by modern naturalists to the class of animals of which we have now to speak; the only one of these terms which will require explanation is the first; it comes from the Greek, and means headless, so an Acephalan is a molluscous animal without a head, as

\section{THE OYSTER,}

Which may be considered as the King of Bivalves; his palace, to be sure, is somewhat rough and rugged outside, but within, its walls are smooth and polished, lustrous and iridescent, and altogether beautiful; of a nacrous or pearly appearance, now flushing into a rose tint, now fading into pure white, and adorned sometimes with goodly pearls of price; truly this monarch of the Conchifers has a habitation worthy of a prince, wherein he lives in right royal state. Our readers may smile perhaps at the idea of the solitary Oyster doing this, down there on his mud bank or rocky anchorage ground, shut up in his dirty-looking shells, and holding, as it scems, commune with no one, not eren his fellow mollusks; how can he be said to live in royal state, or indeed any state at all, except in a most weary, stale, flat, and unprofitable one? And this only shews how erroneously those often judge who do so hastily, and from first appearances.

If we take a peep through a microscope, under the dircetion of a naturalist named liymer Jones, we shall see that "the shell of an Oyster is a world occupied by an innumerable quantity of animals, compared to which the Oyster itself is a colossus. The liquid enclosed between the shell of the Oyster contains a multitude of embryos, corered with transparent scales, which swim with case; a hundred and twenty of these embryos, placed side by side, would make an inch in breadth. This liquid contains besides, a great variety of animalculæ, five hundred times less in size, which give out a phosphoric light. Iet these are not the only inhabitants of this dwelling-there are also three distinct species of worms." 
Let us see if there are any hard names here that want explaining before we go any further. The first we stumble upon is Colossus, which comes from the Latin, and means a great image or statue, like that which ancient historians tell us once bestrode the entrance to the harbour of Rhodes. Embryo comes from the Greek, and means something small and unfinished, that is to expand or grow into a more perfect form, as the seed into a plant. Animalculce, are minute or very small animals, such as cannot be distinguished without the help of a microscope, hence they are sometimes called microscopic animals; this word comes from the Latin animalis, which means having life. Phosphoric signifies luminous, or giving out light. The Greek name of the morning star is Phospha. In Latin, Phosphorus is a term applied to a substance which chemists extract from bones and other animal matter, and which, when exposed to air, burns with a pale blue light, like that emitted by the glow-worm. Many of the oceanic or sea animalculre are exceedingly phosphorescent, so that by night, the waves appear like billows of flame. Of this luminosity of the ocean, as it is termed, we shall have to speak on another occasion. We will now return to the Oyster, who, it will be seen, is by no means so solitary in his bivalve palace as might be supposed. He has his torch-bearers, and other attendants, quite a host of them, no doubt magnificently dressed, if we could but see them to advantage, and well instructed in the sereral duties which they have to perform. Oh yes, certainly, as the Irish poet has said,

"Of all the Conchiferous shell-fish, The Oyster is surely the King;"

Shall we continue the quotation? and say

"Arrah Mick, call the people who sell fish, And tell them a dozen to bring:

For it's I that intend to demonstrate, The creature's phenomena strange,

Its functions to set every one straight,

And exhibit their structure and range."

Scarcely will our limited space permit us to do this, but a few of the most remarkable particulars about this common 
Acephalan, we feel called upon to set before our readers.

First, then, it belongs to the class Cunchifera; this is a word which we must stop to examine a little; it seems to come from the Latin concha, which means a shell-fish with two shells, in other words a biralre mollusk. Second, our Orster belongs to the class Pectinide. Sow pecten is the Latin for a comb, and this class includes those biralre shells whose edges are toothed, or, as it is said, pectinated; in the scallop and the cockle shells this peculiarity is more obserrable than in those of other members of the class, and these form the trpical, or so to speak, pattern genus, pecten. Thirdly; the Common Oyster is a ILonomyarien Conchifer. Als! that 's something like a name for the accphaloid monarch! Look at these two words, mono-myerian, di-myarian, you know of course that mony-syllable means one srllable, and dis-srllable means two. You sometimes hear of a person who leads a monotonous life, and you think perhaps of the Orster shut up in his shell all alone, one by himself; this notion rou now know to be a false one; although it is true that he has but one abductor muscle, and therefore belongs to the dirision of the Pectinide fimily called Monomyaria, while the Pearl Oyster has two, and therefore belongs to that termed Dimyaria. If, as ther say, there is reason in the roasting of eggs, surely there must be in the names given to the classes and divisions of shells. We hope to have succeeded in making the why and the wherefore in this case somewhat plain;-one-twoand away we go out of this maze of hard names. But what about the abductor muscle, above spoken of? well, this must be explained; abduce, coming from the Latin abduco, means to separate, to draw away, hence we have abduction. During the life of an Oyster, the usual and natural state of the shell is that of being kept open for a little distance, to allow the water necessary for its nourishment and respiration to flow in and out: but as a security against danger, it was necessary to furnish the animal with the means of rapidly closing the shell, and retaining the valres in a closed state. These actions being only occasional, yet requiring considerable force, are effected by means of a muscular power, for which purpose one or two, or sometimes more strong muscles are placed between the ralres, their fibres passing directly across from the 
inner surface of one to that of the other, and firmly attached to both, and these are called the abductor muscles, because their office is to draw or pull; how strongly they do this those whose business it is to open Oysters can best tell; if the animal within were not alive, the process would not be a difficult one, as in that case the muscles would be relaxed, and the shell would come open of itself, so that actually people who eat Oysters directly they are opened, swallow them "all alive- 0 !"

If a pair of the shells from which the delicious morsel has been extracted, be taken in the hand, it may be noticed that one is much thinner, smoother, and flatter than the other; this is the side most exposed to the action of the water; the rougher and rounder side is that which is attached to the rock, or other substance to which the animal forms an attachment, that is usually life-long. The two portions of the shell are joined together by a hinge of curious workmanship, which is formed of the inner layer of the shell, and strengthened by a ligament which is wonderfully elastic; when the shell is drawn together by the abductor muscles, the ligament is at full stretch, and as soon as they relax at all, it contracts, and causes the shell to gape. This process is repeated as often as may be necessary for the safety and sustenance of the animal within, whose mouth is situated at the narrowest part of its habitation, namely, near the joint of the hinge, which connects its upper and under shell. The anatomical structure of the Oyster is more perfect than would be supposed, from its apparently low state of organization; it has a heart, liver, and intestinal canal, and a bag near the mouth, which answers the purpose of a stomach. Its breathing organs are gills, closely resembling those of most other fish; it has little ressels which convey the bile from the stomach to the liver, and may perhaps be subject to bilious attacks, as well as those who swallow this curious piece of organization at a mouthful, without thinking at all of the goodly structure they are demolishing. There is the tiny heart with its series of blood-vessels, just as perfect as in the larger animals. There are the nerves in the shape of minute feelers, which appear to be acutely sensible not only of actual contact with foreign bodies, but also of sounds and morements from without. A 
very nice sense of feeling appears to reside in what is called the beard, in scientific language bissus; this is a kind of double fringe to the two lobes of the mantle, or sac, as it is called, which envelopes the body of the animal, and floats free from the shell, exeept just at the part nearer the valse where it is attached.

We have just spoken of the beard of the Oyster, and this reminds us of a conundrum which may serve to amuse our readers, and enliven these dry details a little. Why is an Oyster the most anomalous, that is strange, contradictory, creature in existence? Do you give it up? Well then it is because

\section{"It wears a beard without any chin, And leaves its bed to be tucked in."}

Again, by this allusion to the "tucking in" of Oysters, a phruse more expressive than polite, we have recalled to memory the saying of a quaint old author, that they are "ungodly, uncharitable, and unprofitable meat; ungodly, because they are eaten without grace; uncharitable, because they leave nothing but shells, and unprofitable because they must swim in wine." Not, generally, howerer, are they caten in this lusurious manner, a little pepper and vinegar is all they commonly get in the way of sauce, and those who swallow them thus accompanied, seem to do so with infinite relish. A very long chapter, if not a whole book, might be written about the historical associations of Oysters, for which our country has been famous, as fir back as the lime of the first Roman invasion; much, too, might be said about the Oyster beds and fisheries, which give employment to thousands of our industrious population, but all this has so little to do with natural history, that we can find no excuse for dwelling mpon it here. It is quite within the range of our subject, howerer, to state that the "spat" or "spawn" of the (Yyster is east about the beginming of May: at first it rescmules a drop of greenish tallow, but by the aid of the microscope it may be seen to consist of a great number of minute particles, each of which is an egg, and will by-and-by become a perfect fish; these increase in size rery rapidly, and aiter floaing about for a while, sink to the bottom, and become attached to rock or some other substance, 
in which position, if not violently detached or removed, they complete their growth, and live out the term of their natural life. Their food is minute animalculæ, and microscopic regetation, on the nature of which their flavour greatly depends.

They have many enemies besides man; the whelk, and the crab, the sea-star, or "five fingers," and the large drum-fish, which swallows them almost by the bushel, shells and all; these help to thin the Oyster-beds, and make the dredger's labours less remunerative than they would otherwise be. Here is a

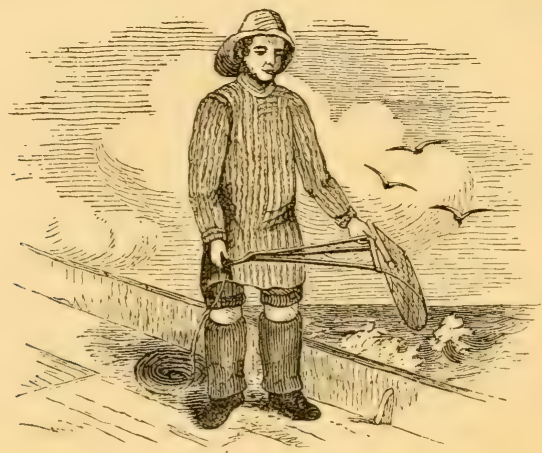

pieture of one as he stards in his boat just about to throw his dredge into the sandy bottom, where he knows the delicious testaceans do, or ought to, lie most thickly. The dredge, which is a triangular iron frame with a net over the bottom, will naturally sink, and when the line to which it is attached ceases to run out, the dredger will put his bcat in motion, and draw it thus over the O5ster-bed, and then pull it up filled, it may be, with little fat "Miltons," or large "Colchesters," or such other lind as the spot is known to yield.

The Latin for Oyster is Ostrea, and that is a name giren to a genus of the Pectinide family, comprising beside the O. edulis, or Common Oyster, many other specics. Edulis means eatable. Some naturalists divide these Ostraceans into two groups, first with simple or undulated, but not plaited ralres; second, those which have the borders of their valres distinctly plaited. 
To the first group belong the Common Oyster, and between thirty and forty other living species which are found principally in warm and temperate latitudes. In the Polar ocean none have been discorered, and in the hotter climates they are most abundant, being found in large beds or banks near the coast, and often attached to rocks and even to trees which grow by the water, so that the accounts of some old travellers who stated that they saw Oysters growing upon trees, were not so false as many supposed them.

The annexed figure is that of the Cock's-comb Oyster,

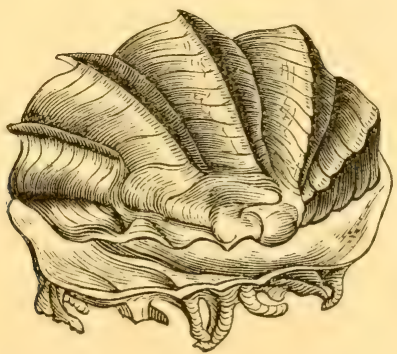

Ostrea Crista-Galli, a native of the Indian Scas, and a rery remarkable shell, on account of its crooked or deeply indented form; the specific name means cock's-crest. The Chinese

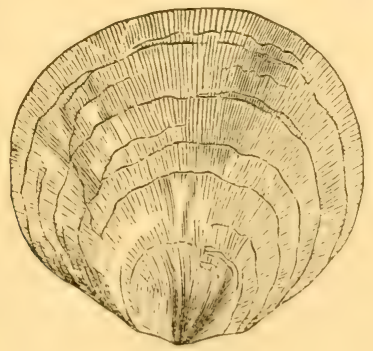

Window Oyster, called Placeme Plecente, which we may; if 
we like, translate into a pleasant or agrecable cake; the shell, it will be seen, is round like a cake, and its smoothness and regularity of form render it agreeable to look upon; this species too comes from the Indian Seas, where it is taken on sandy bottoms. The American Spiny Oyster, or Spondylus Americanus,

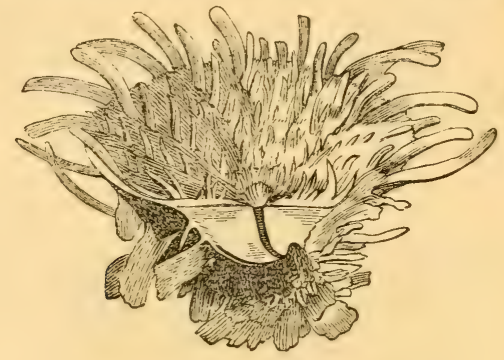

brings us into another family, that of the Water Clams, called by naturalists Spondylidie; with the spines stuck out every way, and no way in particular, it looks like a head of hair greatly in need of the assistance of one of its pectinated relatives. The specific name of this curious shell explains itself; the generic name comes from the Latin Spondylisa kind of serpent.

Passing over the family Malleide, or Hammer Oysters, we come to the Meleagrinide, or Pearl Oysters, of which Fig. 1, Plate VIII, is an example, this is the $M$. Margaritifera of naturalists, the mollusk in whose shells pearls are chiefly found. Here are two long words; Meleagris is the Latin for a Guinea or Turkey Hen, to the markings of whose plumage naturalists might have imagined the shells of this genus bore some resemblance. There was, says the mythology, a celcbrated hero of artiquity named Meleaga, but we can hardly suppose that there is any association between his name and that of a genus of Oysters, of which edible we read the ancients were very fond, and they are said to have had a fancy not only for the mollusk itself, but also for the pearls found in its shell, which at their luxurious banquets they dissolved in wine, to make the draughts richer, or at all events more expensive; and this 
brings us to the specific name of the Pearl Oyster, Arargaritifera, which comes from the Latin IIargarita - a pearl; the French use this word slightly altered in the spelling, thus IFarguerite for both a daisy, and

\section{A PEARL.}

Trirs jervel, so highly valued for its chaste beanty, is but a secretion of animal matter, resulting from the efforts of some uneasy mollusk, annoyed by a foreign substance, which has found its way into his habitation, to make the best of an unavoidable evil by enclosing it in a soft smooth covering. Let us imitate the Oyster, and when annoyed or afflicted, by meekness and patience, and christian charity, strive to turn our vexations and troubles into "pearls of great price," and "goodly pearls," like those mentioned in scripture.

It is on the north-west coast of the Island of Ceylon, in the Indian Ocean, that the Pearl Oyster most abounds, and there it is that the Pearl fishery is conducted in the most cxtensive, systematic, and successful manner; this fishing commences at the beginning of Mareh, and upwards of two hundred boats are usually employed in it; in each of these boats are ten divers, who go down to the Oyster-beds, five at a time, and so relieve each other; there are besides thirteen other men who manage the boat, and attend to the divers. Altogether it is computed that from fifty to sixty thousand persons, in some way engaged in the fishery, or preparation, or sale of the pearls, assemble at and near the scene of operations, which must be indeed a busy one. The number of Oysters taken during the period of the fishing, which is about a month, must be prodigious. One boat has been known to bring on shore, in the day, as many as thirty-three thousand; they are placed in heaps, and allowed to remain until they become putrid, when they undergo a rery elaborate process of washing and separating from the shells, which are carefully examined and deprived of their pearly treasures. The stench arising from the decomposed animal matter is deseribed as horrible, and the whole process filthy and loathsome in the extreme; yet out of the slime and mud and disgusting efiluvia, cone every year gems of inestimable value, calculated to atorn the bris 
of beauty, and form ornaments the most pure and delicate that can be imagined. For the exclusive right of fishing on the banks of Ceylon, for a single season, as much as $£ 120,000$ have been paid to the English government by one person, who sublets boats to others. Pearls vary greatly in value according to their colour and size; those which are perfectly white are the most valuable; next to these are those which have a yellowish tinge; the smallest kind, used for rarious ornamental purposes, are called seed pearls, the refuse is made into a kind of confection called chimum, highly relished by Chinese epicures. A single Osster will sometimes contain several pearls, which are generally cmbedded in the body of the animal, but are sometimes fixed to the shell; it is recorded of one rich mollusk, that there were found in his possession no less than one hundred and fifty precious jewels; he must have been a miser, or perhaps he had taken them in pledge from his less provident neighbours.

From the earliest time, pearls have been considered as valuable ornaments; they are mentioned in the book of Job, (see chap. xxviii, verse 18th.,) and are often alluded to by Greek and Roman writers. Various attempts have been made to imitate them, and one mode of producing them, practised, it is said, more than a thousand Jears ago, is still carried on in China. In the shells of Pearl Oysters, holes are bored, into which pieces of iron are introduced; these wounding and irritating the animal, cause it to deposit coat upon coat of pearly matter over the wounded part, and so the pearl is formed. Artificial pearls are made of hollow glass globules or little globes, covered on the inside with a liquid called pearl-essence, and filled up with white wax. Historians speak of an ancient traffic in natire pearls carried on by this country; and in modern times, British pearls of considerable value have been discovered, one not many rears since, by a gentleman who was eating oysters at Winchester, was valued at two hundred guineas. Generally, howerer, the pearls of this country are inferior in the two requisites of colour and size.

Interesting accomts of Pearls and Pearl-fishing, will be found in "the Penny," and "Saturday Magazines," and many nther works casy of access. There our young readers may 
learn of the perils and dangers to which the poor divers are exposed from the voracious sharks, which hover about the fishing grounds, and make a dash at their victim, heedless of the written charms, with which the priest or shark-charmer has provided him previous to his descent, and of much more than we ean find space here to tell. All we can now do is to give the portrait, as drawn by Thomas Hood, of a lady who takes up her abode in all the pearl-producing bivalves, and who is therefore, perhaps on this account, called

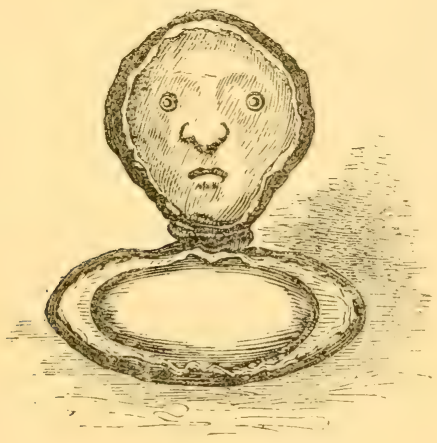

THE MOTHEIR OP PEATI.

\section{THE MUSSEL AND THE COCKLE.}

Ir is in the Dimyaria division of the Conchifera that we must look for these familiar bivalves, the Mussel, or, as it is sometimes spelled, Muscle, and the Cockle; the former called in scientific language Nytilus, which in Latin means simply a shell-fish, and the latter Cardium, which may have reference to the hinge of this bivalve, or the heart-shape assumed by several of the species; cardo, in Latin, signifying the hinge of a gate, and cardesco, a stone in the shape of a heart.

It is to the Mytilide family that we shall first direct our 
attention, and here we find tile Common or Edible Mussel, (AI. edule,) and many other species, in all of which the shell is more or less elongated, or lengthened out, and pointed at oive end. The members of this family are abundant on most rocky coasts, where facilities are afrorded for the mollusks to moor themselves to rocks, stones, and other substances covered at high-water, but left dry by the retreating tide. They are not, however, confined to shores of this description, but are sometimes found in vast numbers on low sandy or pebbly flats, which run far out into the sea; these are called beds of Mussels, and are, like the Oyster grounds, specially cared for and protected. As a ship by its cable, so commonly the Mussel, by its bissus or beard, is made fast to its anchorage-ground, be it pebbly or sandy beach, or jutting rock. Sometimes, however, the mollusk travels, and this is how it manages to do so; it has a stout fleshy foot, in shape something like that of a chubby child, and this it can advance about two inches beyond the edye of the shell, then fixing the point of it to a picee of rock or any other body, and contracting it, the shell is drawn onward, and sure, though slow, progress is made in any desired direction. The Pinna, as the marine Nussel is called, has a foot which is cylindrieul in shape, and has at the bottom a round tendon, almost as long as itself, the use of which appears to be to gather in and retain the numerous threads with which, when inhabiting the shores of tempestuous seas, it lashes itself fast to the fixed objects around; these thrends are fastened at various points, and then drawn tight by the animal, whose instinct teaches it that its brittle shell would soon be broken in pieces, if suffered to roll hither and thither at the mercy of the wares.

The Mussel has a very curious method of preparing its cable for this service; it is not woren, nor spun, nor drawn out of the body, like the web of the spider, but produeed in a liquid form, and east in a mould which is formed by a groove in the foot, extending from the root of the tendon to the upper extremity; the sides of this groore are formed so as to fold over it and form a canal, into which the glutinous or sticky secretion is poured; there it remains until it has dried into a solid thread, when the end of it is earried ont by the foot, and applied to the object to which it is to be 
attached; the canal is then opened through its whole lenuth to free the thread, and closing again is rearly for anotlie casting; as if conscious how much depends mpon the security of his lines, the animal tries every one after he has fixed it by swinging itself round so as to put the threats fully on the stretch; when once they are all firmly fixed, it scins to have no power of disengaging itself from them; the liquid matter out of which they are formed, is so very glutinous, or ghe-like, as to attach itself firmiy to the smoothest bedies. The process of producing it is a slow one, as it does not an)pear that the Pinna can form more than four or five in the course of twenty-four hours. When the animal is disturbed in its operations, it sometimes forms these threads too hastily; they are then more slender than those produced at leismre, and, of a consequence, weaker. On some parts of the Mediterranean coast, as in Sicily, gloves and other articles have been manufactured from the threads of this mollusk; they resemble very fine silk in appearance.

The foot of the Cockle, of which we here give a figure, is commonly employed in scooping out the mud or sand, beneath which it conceals itself; this useful limb assumes the form of a shovel, hook, or any other instrument necessary for the purpose; it appears to be a mass of muscular fibres, and to possess great power. As a boatman in shallow water sends his vessel

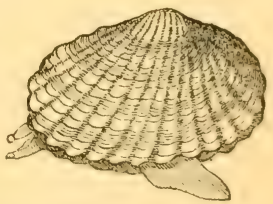
along by pushing against the bottom with his boat-hook, precisely so does Mr. Cardium travel; he doubles up his foot into a club, and by an energetic use of it as a propeller, makes considerable headway along the surface of the soft sand beneath the waters. In this way, too, some members of the genus solen force their way through the sarid; while those called Tellina spring to a considerable distance, by first folding the foot into a small compass, and then suddenly expanding it, closing the shell at the same time with a loud snap; so that you see these sober-looking mollusks are sometimes frolicksome fellows; this is an enforecment of the lesson, judge not by appearances.

Some of the species, both of the Mnssel and Cockle families, 
have very beautiful shells. We give a representation of one of each, on Plate VIII. Fig. 2 is the Magellanic Mytilus, ( $\boldsymbol{M}$. Mragellanicus,) found chiefly in the Straits of Magellen; it is generally four or five inches long, the shells when polished are very brilliant, the deep purple colour changing into rich violet, as they are held in different lights. In most cabinets the large fan-like delicate shells of the genus Pinna may be observed; the largest species is that called Pinna flabellum, taken in the Mediterranean; it sometimes exceeds two feet in length. The first of these names is a Latin word signifying, besides a shell-fish, the fin of a fish, or the wing feathers of a bird-hence the term pinion; it refers to the fin-like or winglike shape of this shell. Flabellum means a fan, referring probably to the bissus of the mollusk, which is fine and glossy, like silk, and very abundant.

Many pretty specimens for figuring might be selected from the Naide, a family of Fresh-water Mussels, so called from the Naiades, fabulous divinities of the streams and rivers. The shells of many of these, which are of considerable thickness, are lined with the most brilliant nacre, and in these, as might be expected, pearls are sometimes found. One species, abundant in some English rivers, called the Mya Margaritifera, or, as some say, Uno elongates, has long been celebrated for this valuable production. It was most likely with pearls from this mollusk that Julius Cæsar adorned a breast-plate, which he dedicated to Venus, and hung up in her temple. The rivers Esk and Conway were formerly celebrated as British pearl-fishing grounds; a Conway pearl was presented by her chamberlain, Sir Richard Wynn, of Gwyder, to Catharine, Queen of Charles the Second; and in the royal crown of Britain this jewel is said still to oceupy a place. Sir John Hawkins, the circumnarigator of the globe, held a patent for the pearl-fishery of the liver Irt, in Cumberland. The rivers of Tyrone and Donegal, in Ireland, have, or had, their pearlbearing Mussels; we read of one which weighed thirty-six carats, (a carat is nearly four grains, ) but not being of perfect shape and colour, it was only valued at forty pounds. We also read of another purchased by Lady Glenlealy, for $£ 10$, and found to be so perfect and admirable, that $£ 80$ was afterwards offered for it, and refused. 
These Naide have not a bissus like the Marine Musscls, they are therefore never attached to one object; they use their foot as a propeller in traversing the muddy floor of the pond or river, and they have a very funny way of getting along indeed; first, they open the valves of the shell, put out the foot, and after some little hard work, manage to set themselves up on edge; they then proceed by a series of jerks, leaving a deepish furrow in the mud behind them.

We will now go to Fig. 3, the Spined Cytherea, the Cytherea or Tenus Dione of naturalists; the meaning of the term is the mother of Venus, who was, as you will remember, the goddess of beauty, given to this shell perhaps because it is entitled to oscupy a place at the head of the Cytherea, a genus of the Cardiida, or Cockle, family, of which genus there are about serenty-eight living species; this, as it is the most rare, is also, perhaps, the most beautiful; it is found in the seas of America, and is remarkable for the row of spines on the hinder border of each valve; these vary much in size and number, being in some individuals long and far apart, in others, short, thick, and closely set. The colour of the shell also varies considerably, being sometimes of a delicate rose colour; at others, more of a claret; at others again, bordering on purple. It was for one of the first discorered specimens of this shell, that $£ 1000$ is said to have been given. Truly a Venus of value this; it ought to be called the Queen of Cockles!

Our next example, (see Fig. 4,) is the Spotted Tridacna, (T. maculatus, ) the latter term signifying spotted. In the Chamida or Clam family, is placed the Triduena genus, the discovered species of which are not numerous; they are chiefly found in the Indian seas. The one above mentioned claims pre-eminence for beauty. We cannot quite sce the applicability of the generic name; Tridacnus, in Latin, signifies to be eaten at three bites, but he must be a man of large capacity indeed who conld so devour the head of this family, the Giant Tradacna, ( $T$. gigas,) a single specimen of which has been known to weigh as much as five hundred and serenty pounds; from three to four hundred is by no means an uncommon size. The shell of this giant mollusk is of a very pieturesque shape, something like its spotted congener, as we 
call anything of the same lind or genus, only it is someWhat plainer, and more deeply ribbed and indented. The inside is of a glossy whiteness, and it is frequently used as a basin for garden fountains, or the reception of rills or little jets of water, which sparkle in its stainless hollow. In the church of St. Salpice, at Paris, is a shell of this immense Clam, the valves of which are used as receptacles for holy water; it was presented to Francis the First, by the republic of Venice. Fancy the clapping to of such a pair of ralres, when the animal closes its shell in alarm, and the strength of the cable required to moor it to the rocks or coral reef. The spotted species here figured has a solid and heary shell, very elegantly shaped, and beautifully marked, as will be seen; the greatly reduced size of the figure prevents ansthing like justice being done to the original.

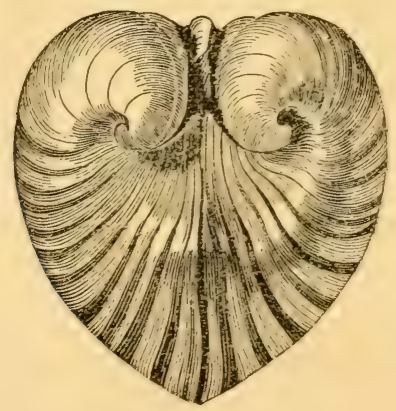

The above is a figure of the Heart Isocardea, (I. cor,) which is also a member of the Clam family, and one of the most elegantly-shaped shells in the whole range of Conchology. It is a nutive of the Mediterranean and other seas of Europe, and has been taken in deep water on the West coast of Ireland. We complete this group with a representation of the curious Arcade family, or Ark shclls, as they are commonly called, because one of the species was thought to resemble the ark built by Noah. Mr. Swainson tells us that the animals of these shells affix themselves to other bodies by a 
particular muscle, which is protruded through the gaping part of the ralres; they also adhere, when young, by means of the bissiform epidermis, or bissus-like outer slin: this species is a native of the Atlantic Ocean and the seas of Europe. The Antique Ark, (A. antiqua,) is rery like the Common Cockle, being of a white colour, and heart-shaped. We gire below a representation of this shell, and also of the shell of the pretty little Pearly Trigonia, (T. margaritacea,) incluled in the Arcade family; this is a rare species, found only in the seas of New Holland.
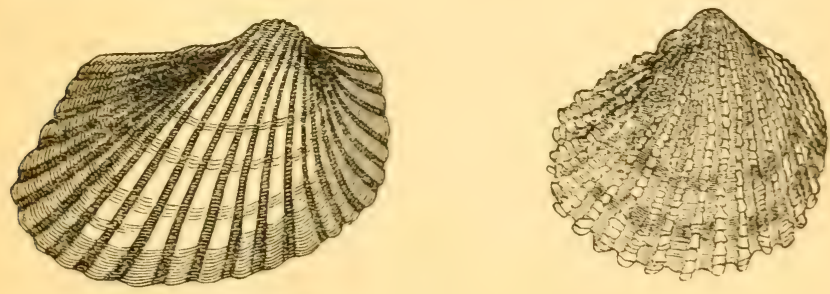

\section{SCALLOP SHELLS.}

Several species of Scallop Shells are found scattered about on our shores; they belong, as before stated, to the family Pectinide, the meaning of which term has been already explained. These shells were called by Cuvier "the Butterflies of the Occan," on account of the various and beautiful colours which they exhibit. Some of them are cxecedingly thin, and brittle as glass; one species found in the Arctic regions, is as transparent as that substance, and is therefore called $P$. vitreus, from the Latin for glass, which is ritreum. One of the commonest of our native Scallops is the St. James' Cockle, ( $P$. Jacobous;) this shell is found in great plenty along our southern coasts; it is often referred to by old writers, on account of having been commonly worn in the hats of pilgrims to Palestine, or the Holy Land, as the scene of our Saviour's life and death was called. Sir Talter Raleigh, 
in his poem called "The Pilgrimage," thus enumerates the different articles considered necessary for a Palmer, as these pilgrims were termed:-

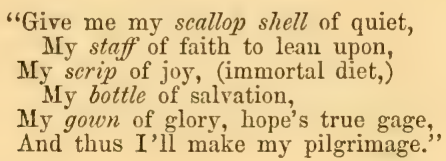

This Mollusk, it may be noticed, like many other bivalves, has a flat, and a concave or hollow shell: in early times when plates and drinking ressels were not so plentiful as they are now, one of these served the former purpose, and the other the latter; thus, in speaking of a feast, a Gaelie or Scottish bard has said-

\section{"The joy of the shell went round."}

Sometimes the species termed Pecten opercularis, was used as the pilgrim's badge; the specific name comes most likely from the Latin operculum, whose meaning has been explained.

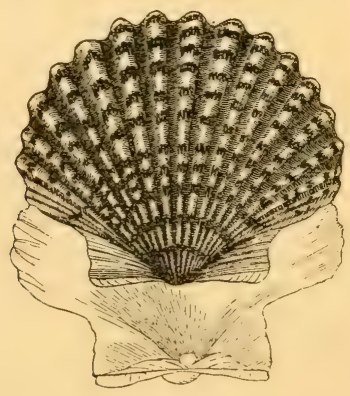

COMMON SCALLOP.

This too, is a common British shell, as is also the little 
speckled Scallop, ( $P$. varia,) which may be found on almost any part of the coast where the water-line is margined with a sandy ridge. The shells are generally about two inches long, of various colours, clouded, speckled, and marked with about twelve ribs. There is a foreign species called the Flounder Scallop, $P$. pleuronectes, which is remarkable for having the two valres of the shell of different colours, the upper one being of a rich reddish brown, and the lower one white: the specific name has reference to this, being compounded of the Latin pleura-something double, and necto-to join. The fish called the Flounder, is brown above and white beneath, hence the English name of this shell. The preceding engraving of the Common Scallop, viewed from the front, shows the flat and concave form of the two valves of this shell, and also the depth of the indentations or ridges.

\section{LIMPITS.}

Axoxg the rocks of the British coast, there are no shells more frequently met with than those of the Common Limpit, Patella vulgatu; they lie scattered about like so many little empty cups, each having, on the death of the mollusk, fallen from the rocky eavity in which it was embedded, and which was just large enough to contain it. Here the animal attaches itself so firmly by its fibrous foot, which is hollow in the centre, and acts like a sucker, that it is almost impossible to loosen its hold otherwise than by inserting something thin, like the blade of a knife between it and the stone. By this power of adhesion, the Limpit is protected from the violence of the waves, and also from its numerous enemies, aquatic birds and animals, which have a relish for its flesh. Still vast numbers are used as food, both by man and the inferior creatures, so that the means of defence furnished to the Limpits of the rock, are not always sure. "The peasantry of the western isles of Scotland," we are told by Miss Pratt, "look to the Periwinkles and Limpits, which abound on the rocks, for their daily meal, often for long seasons, subsisting: 
almost entirely upon this humble food. In the Isle of Syke, the inhabitants are often, at one time of the year, without any other source of provision." Then comes the Sca-gull, and the Duck, and the Pied Oyster-catcher, to feed on the poor little mollusk, the bill of the latter bird being admirably adapted for loosening its hold on the rock.

Patella in Latin signifies a salad-dish, a knee-pan, and sereral other domestic utensils, of a broad shallow make, and hence we find the plural form of the word applied to the Limpit family, whose shells are of such a shape. Members of this family are found on all rocky coasts, except those of the Arctic seas; on Tropical rocks they grow to a large size, and form a valuable article of food. A very curious piece of mechanism is the tongue of the Common Limpit, it is from two to three inches long, and has a spoon-like extremity, so that it looks, when extended from the mouth, like a small snake; if examined through a microseope, it is seen to be armed throughout its whole extent with rows, four deep, of sharp hooked teeth, and between each row are placed two others, which have three points, and are set in a slanting position; the use of this arrangement we cannot at present determine, but no doubt it has a perfect adaptation to the wants of the animal.

There are shell-fish called Key-hole Limpits, which belong to the genus Fissurellida, from fissura-a cleft or slip, from whence comes also fissure. All the members of this genus are distinguished by the aperture at the top of the shell, shaped like a key-hole, which is situated exactly over the breathing organs, and serves as a channel for the water necessary for respiration.

Frequently upon the fronds of the large olive sea-weeds may be found a tiny shell shaped something like that of the Common Limpit; it is of an olive green colour, with blue streaks, and is called, from its clearness, the Pellucid Limpit, P. pellucida. There is also another much like it in appearance, which naturalists call P. loris. To the labours of these little mollusks, according to Dr. Harvey, may be partly attributed the destruction of the gigantic Algæ, (sea-weed.) Eating into the lower part of the stems, and destroying the branches of the roots, they so far weaken the base, that it becomes unable 
to support the weight of the frond; and thus the plant is detached and driven on shore by the waves.

\footnotetext{
"And so the forest tall that groweth, Underneath the waters elear, Does the little woodman mollusk, Level every year;

From small causes, great resultsTeaching you to persevere."
}

\section{ROCK-BORERS.}

Tre family Pholade comprises a group of mollusks, the boring habits of which have long been known; they penetrate wood, hard clay, chalk, and rocks, and devastate the labours of man; they attack the hulls of ships, the piles which form the foundations of piers and break-waters, and they foree themselves upon our attention by the loss of property, as well as of life, which results from their hidden depredations. Of this family, those belonging to the genus Pholus may be more especially likened to the Elomites of Scripture, because they take up their abode in the rock, and hollow out for themselves dwellings therein. With a shell as thin as paper, and brittle as glass, the wonder is how these Rock-borers work their way into and through hard stones. Some naturalists assert that they effect this by means of an acid which decomposes the substance of the roek, and renders it soft; others, that the animal lieeps turning round and round like an instrument called an auger, and so gradually rasps away the surface of the stone with the angles of its shell, but we question whether the shell would not be worn out fir'st in such a process. The generie name of these "stone-piercers," comes from the Greek word Pholeo-to hide, and the rocky chambers which they hollow out for themselves, are as snurg hiding-places as can well be imagined; yet, howerer deep they may go into these gloomy caverns, as we should be apt to suppose them, they need not be in darlness, for it appears that these Pholades emit a most remarkable light, whether phosphorescent or not does not appear to be determined; so strong is it, that it is 
said to illuminate the mouth of the person who eats the mollusk; and it is remarked by Dr. Priestly, that "contrary to the nature of most fish, which gire light when they tend to putrescence, this is more luminous the fresher it is, and when dried its light will revive on being moistened with water." So that in more respects than one these rock-borers are mysteries. The most common of them, perhaps, is the Prickly Pidduck, or Peckstone, ( $P$. dactylus,) which is much used by the fishermen of our coasts as bait; the specific name is the Latin for a fruit shaped like a finger, which is something like the shape of this mollusk, as will be seen by the annexed engraving.

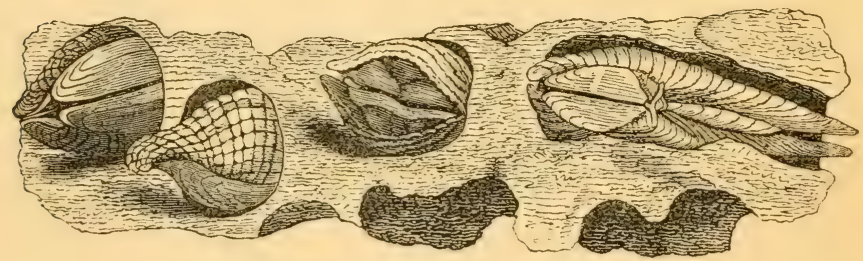

The genus Pholus is rery widely distributed, and all the species have the same boring habits as those of our own coast, which we need not enumerate. Like them too in this respect are the marine worms called Teredo, which make their way into the bottoms of ships, and all submerged timber, but these will be more fully spoken of in another volume. The above figure exhibits the Pholas dactylus as it appears in a section of rock, split open for the purpose of seeing the shelly miner at his work. 


\section{UL T IV A L VES.}

WE have insensibly passed from the Bivalve shells to those composed of several pieces, and therefore called Multivalves; properly, perhaps, the Rock-borers, last described, come into this division, for although their covering consists mainly of two principal portions or valves, yet there are often additional parts; in some a calcarious tube envelopes the whole mollusk, leaving only an opening behind; this is more especially the case with those which most resemble worms, such as the genera Teredina and Teredo, included by Lamarck in the family which he calls Tubulida.

The first group of multivalres we shall have to notice, are

\section{THE CHITONS,}

forming the family Chitonida. The term has a Greek derivation, and means a coat of mail. These mollusks are corered by a shell formed of eight distinct portions, arranged along the back in a single row, and attached to a mantle which resembles leather, being rery tough and wrinkled; the edges of this mantle extend beyond the borders of the plates, which overlap each other, so as to constitute a kind of armour, very different from the conical shell of the Limpit, or the turbinated, that is twisted, case of some of the Borers. The coverings of the Chitons are variously marked, so that each distinct species is known by its peculiar pattern, as a knight of old by the quarterings of his shicld. All the mantles, howerer, have scaly, hairy, or spiny margins. In this coat of mail, the animal can roll itself up like an armadillo, and so be tolerably secure from its enemies; it has an oral foot, the sides of which are corered with small leaflets, and by means of this it can attach itself to rocks, like the Limpit, or travel about in search of adventures. It has no distinct head, therefore it is acepherlons; nor any perceptible eyes. The mouth is furnished with a long tongue, curled up spirally, like a watchspring, and armed with horny teeth.

The members of the ('hiton fomily are numernus, being 
found on most rocky shores; they attain the largest size in the hottest climates, having never been found very far north. The British species are small, and not more than two or three in number; they may be found adhering to stones near low-water mark. We gire a figure of one of these called the I'ufted Chiton, (C. fascicularis; ) this word is from the Latin fascioulus - a little bundle of leaves or flowers, and it refers to the hairy tufts that edge the mantle of this marine slug.

\section{BARNACLES,}

Or, as they are sometimes called, Bernicles, belong to what naturalists term the class Cirrhopoda, sometimes spelled cirripeda, which appears to be derived from the Latin cirrus-a tuft or lock of hair curled, and pente-a foot; hence the term may be translated hairy-footed. Such of our readers as have seen the Common or Duck Barnacle, (Pentalasmis anatifera,) will at once understand the applicability of this term. Many a piece of drift wood comes to land literally covered with long fleshy stalks, generally of a purplish red colour, twisting and curling in all directions, and terminating in delicate porcelain-like shells, clear and brittle, of a white colour, just tinged with blue, from between which project the manyjointed cirrhi, or hair-like tentacles, which serve the purpose of a casting net, to seize and drag to the mouth of the animal, its prey, which consists of small mollusks and crustacea.

This is the Barnacle about which such strange stories are told by old writers, who affirmed that the Barnacle or Brent Goose, that in winter visits our shores, is produced from these fleshy foot-stallss and hairy shells by a natural process of growth, or, as some philosophers of our day would say, of development. Gerard, who, in 1597 , wrote a "Historie of Plants," describes the process by which the fish is transformed into the bird; telling his readers that as "the shells gape, the legs hang out, that the bird growing bigger and bigger 
the shells open more and more, till at length it is attached only by the bill, soon after which it clrops into the sea; there it acyuires feathers, and grows to a fowle." There is an amusing illustration given in Gerard's book, where the youing Geese are represented hanging on the branches of trees, just realdy to drop into the water, where a number of those that have previously fallen, like ripe fruit, and attained their full plumage, are sailing abont rery contentedly. It was part of this theory that the limmacles were of regetable origin, they wrew upoin trees, or sprumg out of the ground like mushrooms; (4) we find in the works of an old poet named Du Bartas, these lines:-

\section{"So slow Bootes underneath him sees}

In the icy islands goslings hatehed of trees,

Whose fruitful leaves, falling into the water, Are turned, as known, to living fowls soon after;

So rotten planks of broken ships do change

To Barnacles. O transformation strange!

'Twas first a green tree, then a broken hull, Lately a mushroom, now a tiying Gull."

'The investigations of moderin science have quite exploded this foolish notion; we now know exactly what transiommations the Barnacle undergoes; strange enough some of then are, but it does not change into a Goose, although its specific name has reference to that bird, being derived from ancls, the Latin for Goose.

The shell of the Barnacle is composed of five pices joined together by membranes; four pieces are lateral, that is to sily, they form the sides, the word comes from the Latin latur: a side; the other is a single narrow slip, which fills what would otherwise be an open space down the back between the valres; these parts of the shell appear to be somewhat loosely conilected, so as to allow free action to the animal lodged within, which is enclosed in a fine skin or mantle. The month is placed at the lower part, near the opening, whence the cirrhi issue forth; this mouth is a curious piece of mechanism, being furnished with a horny lip corered with minute polpi, or feelers; there are three pairs of mundibles, that is jaws, the two outer ones being horny and seriated, that is jugrged or toothed like a saw; the inner vile is soli and nembranous, 
that is, composed of little fibres, like strings, crossing each other, as we see what are called the reins in a leaf.

Much more might be said about the internal structure of the Cirrhopods, or Baleni, as the Barnacle group is sometimes called, from the Latin Butunus-a kind of acorn. By some naturalists, the term is not applied to the stalked Cirmlipoda, like that we have been describing, but only to the sessile kinds, that is, those which set close or grow low; from the same Latin root comes the English word session-a settling. The coverings of these Dwarf Barnacles are sometimes called acorn shells; they are commonly white, of an irregular cone shape, composed of several ribbed pieces, closely fitted together with an opening at the top, closed by an operculum, or stopper.

These shells cover in patches the surface of exposed rocks, divift rood, and any other substance. Some of the mollusks affix themselres to the bodies of Whales, others form a lodgment in the hollows of corals and sponges. Once fixed they remain so during life, taking their chance of such suitable food as may come within their limited sphere of action. At an exrlier stage of their existence, both their shape and habits are very different, being lively little creatures, swimming about hither and thither like water-fleas. They are about the tenth of an inch long, and of most grotesque appearance, having six jointed legs set with hairs, the whole being so arranged that they act in concert, and striking or flapping the water, send the little body along in a series of bounds; then the creature has two long arms, each furnished with hooks and a suclier, and a tail tipped with bristles, which is usually folded uj under the body; its pair of large staring eyes are pedunculuterl, that is, set upon foot-stalks; it has a house on its back, like a biralve shell, into which it can collect its scattered members when occasion requires. When of sufficient age to settle itself in life, and become a staid member of submarine society, it fixes itself to some conrenient object, throws away its eyes as no longer useful, gets rid of its preposterous limbs, enlarges its house, and sits down to fishing in a smiall way for an honest and respectable livelihood.

A piece of timber corered with Stalked Barnacles, wriggling and twisting about like so many helmeted snakes, and waving their plume-like cirrti, is a very curious sight. They some- 
times attach themselres to ship's bottoms in such numbers as to retard their progress through the water; thes do not, howerer, bore into and destroy the timber, like the Teredines, or ship worms, to which we hare alluded in our brief notice of the Plocludce. The growth of Barnacles must be rery rapid, as a ship perfectly free from them, will often return after a short royage, with her bottom below the water line completely covered.

We give a representation of a group of these stalked mollusks, as they appear affixed to a piece of timber. This is the Common, or Duck Barnacle.

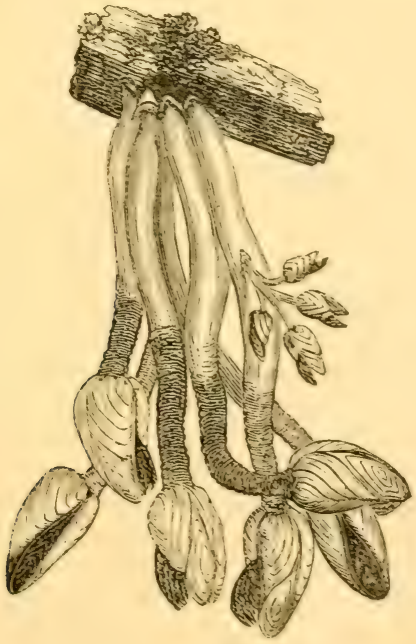

CUTTLE FISH.

STRAxGE and monstrous as are the forms of many of the creatures that inhabit the deep, there are perhaps none more so than those belonging to that division of the class Cephatoporda, 
called Sepia or Cuttle-fish. But before we go any further let us enquire what is meant by a Cephalopod. Our readers have already learned that G'asteiopod means stomach and foot, and that acephalous means hearlless; now here we have a word which takes a portion of each of the others, cephal-head, and peda, or poda-a foot, consequently ceph-a-lo-po-da, is a class of molluscous animals which have their feet, or organs of motion, arranged around the head, something, you may suppose, like that celebrated hero of nursery rhymes,

"Tom Toddy, all head and no body."

Only our bag-shaped Mr. Scpia, with his great round staring eyes, and numerous leg's or arms, whichever you please to call them, all twisting and twining about like so many serpents, is a much more formidable looking individual. A strange follow is this altogether; he has a shell, but he does not use it for a covering, he carries it inside of him, and it serves the purpose of a sort of back-bone; it is horny and calcarious, light and porous, as our readers well know, having most likely often used it to take out unsightly blots, or erase mistakes in their copy or cyphering books.

When Mr. Sepia wallis abroad, he sticks his little round body upright, so that his eyes, and mouth, which is armed with a parrot-like beak, are brought close to the surface orer which he passes, while his long twining legs go sprawling about in all directions; on the insides of these legs are a great number of small circular suckers, by means of which the animal can fix itself to any object so tightly that it is almost impossible to detach it without tearing off part of the limb. Woe be to the poor unfortunate fish that chances to come in its way; the snaky arms are thrown around it, and made fast, and away goes the cephalopod for a ride, eating on the road to lose no time, on the fiml steed that carries it. In some species each of the suckers has a hook in the centre, which of course renders the hold jet firmer, and no doubt adds to the disagreeable sensation which their tight compression must eause; it is likely that these hooks are inteuded to retain the hold of soft and slippery pres, which might otherwise be too agile for the "ugly customer," that would 
affectionately embrace it. But Mr. Sepia, though well armed in front, is rather open to attacks in the rear of his soft naked body; to provide for such an emergency, he is furnished with a little bag of inky fluid, which he squirts out in the face of his pursuer, and eseapes under cover of the eloud; this is the substance used by painters, and called sepia, whence the generic name of the mollusks which produce it.

In the British seas none of these ecphalopods attain so large a size as to be formidable to man, as they do in warmer climates. It was asserted by Dens, an old navigator, that in the African seas, while three of his men were employed during a calm in scraping the sides of the ressel, they were attacked by a monstrous Cuttle-fish, which seized them in its arms, and drew two of them under water, the third man was with difficulty rescued by cutting off one of the creature's limbs, which was as thick at the base as the fore-yard of the ship, and had suckers as large as ladles; the rescued sailor was so horrified by the monster, that he died delirious a few hours after. An account is also given of another crew who were similarly attacked off the coast of Angola; the creature threw its arms across the ressel, and had nearly succeeded in dragging it down, and was only prevented doing so by the severing of its limbs with swords and hatehets. A diligent observer of nature has asserted that in the Indian seas Cuttle-fish are often seen two fathoms broad across the centre, with arms nine fathoms long. Only think, what a monster! with a body twelve feet across, and eight or ten legs like water-snakes, some six and thirty feet long. Well may it be said, that the Indians when they go out in boats are in dread of such, and nerer sail without an axe for their protection.

There is a story told by a gentleman named Beale, who, while searching for shells upon the rocks of the Bonin Islands, encountererl a species of Cuttle-fish called by the whalers "the Rock-squid," and rashly endearoured to seeure it. This cephalopod, whose borly was not bigger tham a large elenched hamd, had tentacles at least four feet across, and haring its retreat to the sea cut wifl by Mr. Beale, twined its limbs around that gentleman's am, wilich was bared to the shoulder for the purpose of thrusting into holes of the rocks after shells, and cindearoured to get its horny beak in a position for biting. 
The narrator describes the sickening sensation of horror which chilled his rery blood, as he felt the creature's cold slimy grasp, and saw its large staring eyes fixed on him, and the beak opening and closing. He called loudly for help, and was soon joined by his companion, who relieved him by destroying: the Cuttle-fish with a knife, and detaching the limbs piece by piece.

There are sereral species of these cephalopods; the most generally distributed appears to be the Octopus vulgaris, or Common Cuttle-fish, which is sometimes found on our own shores, where also may be obtained the Common Sepiola, $S$. vulgaris, usually about three inches long, and the Officinal Cuttle-fish, S. Officinalis, which is about a foot in length; we give below small figures of each of these three species, to show the difference in the shape: the tro last, it will be observed, hare, in addition to the eight tentacles, which give the generic name Octopus, signifying eight, two long side arms, the use of which does not appear to be rery clearly determined.

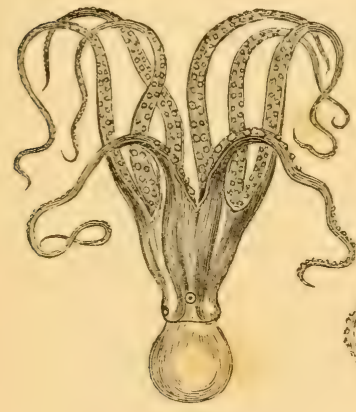

o. TUTGARIS.

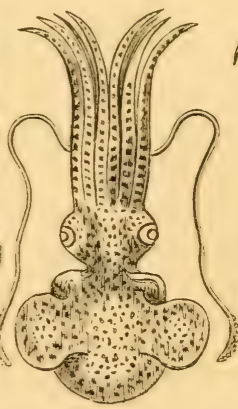

s. TULGARIS.

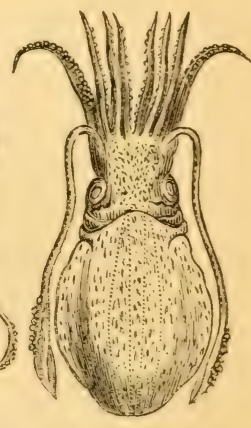

s. OFFICIMATIS. 


\section{NAUTILUS AND AMNONITE.}

Tinf Tautili are called testaceous cephalopols, our reader's know, or ought to linow, the meaning of both these terms. Like the Cuttle-fish they are sometimes called Polypi, becanse they have many arms or tentacles, the word poly, with which a great number of English words commence, being the Greek for many. An ancient writer named Aristotle, after describing the naked cephalopods, says, "There are also two polypi in shells; one is called by some, nautilns, and by others, nauticus. It is like the polypus, but its shell resembles a hollow comb or peeten, and is not attached. This polypus ordinarily feeds near the sea-shore; sometimes it is thrown by the wares on the dry land, and the shell falling from it, is caught, and there dies. The other is in a shell like a snail, and this does not go out of its shell, but remains in it like a snail, and sometimes stretches forth its cirrlii." The first of these animals, there can be no doubt, is the Argonant, or Paper Tautilus, and the latter that which is called the True Nautilus, of both of which species let us say a few words, which we will introduce by quoting some beantiful lines from a poem called "the Pelican Island," by James Montgomery.

\footnotetext{
"Light as a flake of foam upon the wind,

Keel upwards from the deep, emerged a shell, Shaped like the moon ere half her orb is filled: Fraught with young life it righted as it rose, And moved at will along the vielding water. The native pilot of this little bark Put out a tier of oars on either side: Spread to the wafted breeze a two-fold sail, And mounted up and glided down the billow, In happy freedom, pleased to feel the air, And wander in the luxury of light."
}

The tiny mariner here alluded to, is the Paper Tautilus, common in the Afediterranean and some tropical seas; its scientific name is Argonatute argo. In the mythology, we rearl that Argo was the name of a ship that carried a certain Greeian named Jason, and a crew of argires in search of adrentures; some say that the term is derived from a Greek word signifying swift: this party of mariners, said to be the first that (ver. 
sailed upon the sea, was called Argonauts, or, as it might be freely translated, seamen of the ship Argo. Nauticus, in Latin, signifies anything relating to ships or navigation, and here you have the whole origin of the name of this little Argonaut, about which we must sing you a song witten by Mary Howitt. before we proceed further:-

"Who was the first sailor; tell me who can;

Old father Neptune?-no, you're wrong,

There was another ere Neptune began;

Who was he? tell me. Tightly and strong,

Over the waters he went-lie wont,

Over the waters he went!

Who was the first sailor? tell me who can;

old father Noah!-no, you're wrong,

There was another ere Noah began,

Who was he? tell me. Tightly and strong,

Over the waters he went-he went,

Over the waters he went.

Who was the first sailor? tell me who can;

Old father Jason?-no, you're wrong,

There was another ere Jason began,

Do'nt be a blockhead, boy! 'I'ightly and strong,

Over the waters he went-he werit,

Over the waters he went.

$H a$ ! ' $t$ is nought but the poor little Nantilus-

Sailing away in his pearly shell;

He has no need of a compass like us,

Foul or fair weather he manages well!

Over the water he goes-lie goes,

Over the water he goes."

Many more poems of the like nature tre might quote, for this little shelled cephalopod has been a farourite with the poets time out of mind, and in some instances they and the iess imaginative naturalists have disagreed in their accounts of its form and operations, for instance, Pope says-

"Learn of the little Nautilus to sail,

Spread the thin oar and eatch the driving gale."

"Catch a fiddle-stick," say some naturalists, the little Nautilus does nothing of the sort; and if you go to him to learn navigution, you will never be much of a sailor; he may teach you how to siuk to the bottom and rise again, and that kind 
of knowledge might be worth something to you if you could breathe under water; and he might teach you how to swim, but not how to sail, for in spite of all poctic theories, he does the former aud not the latter. Most usually he walks about at the bottom of the sea on his long arms, something like the Cuttle-fish, feeding on the marine vegetation; the shell is then uppermost; if we could look inside of it we should see numerous little chambers or cells, the larger and ontermost of which only are inhabited by the mollusk, the others being filled with air render the whole light and buoyant. Through the centre of these chambers, down to the smallest of them, runs a membranous tube which can be exhausted or filled with fluid at the pleasure of the animal, and the difference thus effeeted in the woight of the shell enables it to sink or swim; in the latter case, up it goes to the surface, and "keel mpwards from the deep," emerges, as the poet has suid, but once there it soon reverses its position. The shell becomes like a boat it is true, but its inhabitant neither points a sail nor plies the oar, but propels itself along stem foremost by a muscular action, which by alternately compressing and loosening a lind of siphon, throws out jets or gushes of water, which by the resistance they meet with from the surroumding fluid, give the desired onward motion, and amiy the swimmer goes, his long arms gathered elosely together, and streaming behind like the tail of a comet, and its round eyes keeping a sharp look-out on either side. Should it esjy danger, the body and limbs are withdram into the shell, and the fluid driven through the central tube, so as to compress the air in the pearly cells, and down sinks the swimmer once again to his native depths, where

"The floor is of sand like the mountain drift, And the pearl shells' spangle the flinty snow; And from coral rocks the sea-plants lift

Their boughs where the tides and billows flow, The water is calm and still below.

For the winds and wares are absent there; And the sands are bright as the stars that glow In the motionless fields of upper air. And life in rare and beautiful forms, Is sporting amid those bowers of stone, And is safe, when the wrathful spirit of storms, Has made the top of the wares his own." 
We give below two figures of the Argonaut, one of which represents him crawling at the bottom of the sea, and the other swimming on the surface.
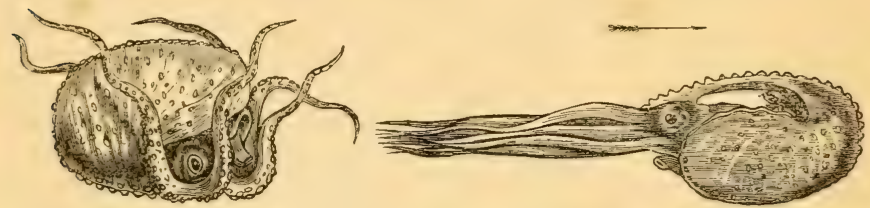

The True, or Pearly Nautilus, (N. Pompilius, ) the origin of whose specific name we have been unable to discover, is much like the Argonaut in appearance and general construction; the shell is externally smoother and more iridescent, it is also generally somewhat thicker than the former kind, and has internally more chambers or divisions; its pearly lustre renders it a beautiful ornament, and the large size it frequently attains a very conspicuous one. Its inhabitant has several peculiarities of organization, which distinguish it from the Argonauts, but into these we need not enter; neither can we pause to describe the other species of nautili, the shells of which, like those of the Cowry and other univalres, are covered with a membrane which hides their beauty. This membrane or mantle sometimes extends some distance beyond the edge of the shell, and, being of a light and films appearance, may have been mistaken for a sail hoisted by the creature to catch the breeze, while its long arms, thrust up into the air or down into the water, may hare been thought to be masts or oars, so that the poets are not so much to be blamed, if they say as Wordsworth does.

"Spread, tiny Nautilus, the living sail, Dive at thy choice, or eatch the freshening gale."

Tearly allied to the Nautili are these beautiful fossil shells called Ammonites, from their fancied resemblance to the horns of a heathen deity or god, called Jupiter Ammon. These shells, at once the wonder and pride of geologists, are found in the chalk formations, and thousands of years must have passed away since they were inhabited by living creatures. 
The Nautili which swam and sported with them at the depths of the ocean, as is proved by the shells of many species found in the same chalky deposits, have still their living representatives, but those winding galleries and pearly chambers once fragile as paper and brittle as glass, now turned into, and surrounded by solid stone, are all shells of extinct species, and we can hardly see and handle them without some degree of awe and reverence; when we reflect on the great and wonderful changes that have passed over the earth since they were formed by a hand divine, instinct with the breath of life, and then to be embedded in the rock as ererlasting characters by which the unborn generations of men might read in history of those changes, and of the providential dealings of God with his creatures. Of these Ammonites, and other fossil shells, much more will hare to be said in our proposed geological volume; the poem which follows will rery appropriately conclude the abore remarks, and our present little work on shells-beantiful, wonderful shells! useful, ornamental, instructive! The subject is one which we would earnestly invite our young readers to study: it is but here introduced; we have picked up a few, rery few, of the wonders and beauties of conchology, and presented them to their notice in the hope that they may be induced to desire a more intimate acquaintance with this branch of natural science, which has been hitherto greatly neglected. To understand it thoroughly, much attention and perseverance will be recuired, but even a slight acquaintance with it will yield both pleasure and profit to the mind.

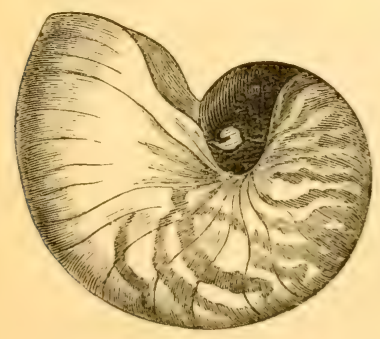

NATTILUS.

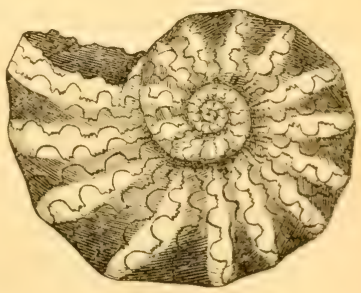

AMMOXITF, 


\section{THE NAUTILUS AND THE AMMONITE.}

The Nautilus and the Ammonite,

Were launched in storm and strife;

Each sent to float in its tinr boat,

On the wide, wild sea of life.

And each could swim on the ocean's brim, And anon its sails could furl,

And sink to sleep in the great sea deep,

In a palace all of pearl.

And their's was a bliss more fair than this, That we feel in our colder time;

For they were rife in a tropic life, In a brighter, happier clime.

Ther swam 'mid isles whose summer smiles No wintry winds annoy;

Whose groves were palm, whose air was balm, Whose life was only joy.

They roam'd all day through creek and bay, And travers'd the ocean deep;

And at night they sank on a coral bank, In its fairy bowers to sleep.

And the monsters rast of ages past, They beheld in their ocean eaves;

And saw them ride in their power and pride, And sink in their billowy graves.

Thus hand in hand, from strand to strand, They sail'd in mirth and glee;

Those fairy shells, with their crystal cells, Twin creatures of the sea.

But they came at last to a sea long past, And as they reach'd its shore,

The Almighty's breath spake out in death, And the Ammonite liv'd no more.

And the Nautilus now in its shelly prow, As o'er the deep it strays,

Still seems to seek in bay and creek, Its companion of other days.

And thus do we, in life's stormy sea, As we roam from shore to shore;

While tempest-tost, seek the lov'd-the lost, But find them on earth no more!
G. F. Richardson. 


\section{N D E X.}

INTRODUCTION.

I'ACI:,

What are Shells. . . . . . . . . iil

Conchology . . . . . . . . . . . . . iv

Bcauty and Value of Shells . . . . . . vi

Uses of Shells . . . . . . . . . . . . . . . . . .

The Inhabitants of Shells . . . . . . . xi

Malacology . . . . . . . . . . . . it,

Classification of Shells . . . . . . . xii

Taking and Preserving Shells . . . . . xiii

The Cabinet . . . . . . . it

On Cleaning and Polishing Shells . . . . xv

Fossil Shelis . . . . . . . ib

U N I A L V ES

The Common Snail . . . . . . . 18

Fresh-water Shells . . . . . . . 23

The Whelk . . . . . . . . . 26

Rock Shclls $\quad$. $\quad . \quad$. . . . 27

Periwinkle . . . . . . . . 29

Trochus, or Top-Shell . . . . . . . 31

Cones, Nolutes, Mitres, and Olives . . . . 35

Cowries . . . . . . . . . 38 


\section{B I V A L VES.}

PAGE.

The Oyster . . . . . . . . . 41

Pearls . . . . . . . . 49

The IIussel and the Cockle . . . . . . 51

Seallop Shells . . . . . . . . 57

Limpits . . . . . . . . . 59

Rock-borers . . . . . . . . . 61

\section{MULTIVALVES.}

The Chitons . . . . . . . 63

Barnacles . . . . . . . . . 64

Cuttle Fish . . . . . . . . 67

Nautilus and Ammonite . . . . . . . 71 


\section{WORKS BY H. G. ADAMS.}

Second Edition, Coloured Illustrations, elegantly bound, price 3s. Gi.

\section{FA V O UITE SONG BIRDS.}

Containing a description of the Feathered Songsters of Britain, with an account ot their Haunts, Habits, and Characteristic Traits; interspersed with choice passigers from the Poets, and quotations from eminent Naturalists.

In Fcap. 8ro. cloth, with Vignette Portraits, price 6s, 6d.

\section{A CYCLOPÆDIA OF POETICAL QUOTATIONS.}

Consisting of Choice Passages from the Poets of every age and country, clitsitied under distinct heads, and alphabetically arranged for ready reference.

In Feap. 8ro., cloth, with Vignette Portraits, price 6s. 6d.

\section{A CYCIOPFDIA OF SACRED POETICAI QUOTATIONS.}

Clissified and arranged under Subject Headings, illustrated by striking Passages from: Scripture, and forming altogether a Complete Book of Devotional Poetry:

\section{THE YOUNG NATURALIST'S IIBRARY.}

Price 1s. each, in Ornamental Cover; 1s. 6d., Cloth Gilt.

I.

NESTS AND EGGS OF FAMILIAR BRITISH BIRDS.

With Eight Plates, containing Forty-eight Figures of Eggs, drawn and coloured from Nature.

II.

BEAUTIFUL BUTTERFLIES-BRITISH SPECIES.

Containing the History of a Butterfy through all its changes and transformations: with Eight Coloured Plates, illustrating Twenty-two species.

III.

B E A U T F U L S H ELIS.

Their Yature, Strueture, and Éses familiarly explained; with Eight coloured l'kiter. and numerous Wood lengravings.

IV.

\section{H U IM I I N G B I R D S,}

Deseribed and Illustrated, and an Introductory Sketch on their strueture, riumage. ete.; with Eight Coloured Plates, and several Wood Engravings.

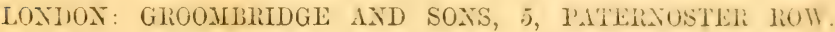




\section{NOW PUBLISHING.}

LOWE'S FOREIGN FERNS.

A NATURAT HISTORY OF FERIS, Exotic and British, in Monthly Parts. Price One Shilling; each Part containing Four Coloured Plates, and numerous Wood Engrarings. By E. J. LOWE, ESQ., F.R.A.S., F.G.S., ete.

"It is really the cheapest work for its excellence we have erer seen."-Athenceum.

A HISTORY OF BRITISE BIRDS. By the REV. F. O. MORRIS, B. A. In 1s. Parts, Royal 8ro.; each containing Four Accurately-Coloured Engrarings. Vol. 5 Completed, price 17s., Cloth Gilt. Cases for binding the Vols., 2s. each.

\section{A NATURAC HISTORY OF THE HESTS AND EGGS OF} BRITISE BIRDS. By the REV. F. O. MORRIS, B.A., In 1s. Parts, Royal Sro.; each containing Four Coloured Plates. Tol. 3 Completed, price 21s. Cases for binding the Tols., 2s. each.

A IATURAL HIGTORY OF BRITISI BUTNERFLIES. By the REV. F. O. MORRIS, B. A. In 1 Vol., Royal Sro., price 20s. It may also be had in 1s. Parts. Case for binding the Vol., 2s.

A BIBLE NATURAT HISTORY. By the REV. F. O. MORRIS, B. A. In Tmperial 16mo., price 10s. 6d., Cloth, with 130 Coloured Engravinus. To be had also in 20 Parts at $6 \mathrm{~d}$, each containing Eight Coloured Plates.

A BOOK OF NATURAL HISTORY. By the REV. F. O. MORRTS, B. A. In Tmperial 16mo., price 10s. 6d,, Cloth, with 160 Coloured Engravings.

THE NATURALIST; a Magazine of Natural History in all its branches. Conducted by the REV. F. O. MORRIS, B.A. Published on the 1st. of each month in Royal 8ro, 24 pages, price 6d., with oceasional Engravings.

THE DAHLIA: its History and Cultiration, with Descriptions of all the best Show Flowers. By ROBERT HOGG. Royal 8ro., price 2s. 6d., illustrated with Nine Coloured Plates, from Original Drawings, expressly executed for this Work, by JAMES ANDREWS.

THE INDIAN WIFE; a Tale. By O. S. ROUND, ESQ. Price One Shilling. 




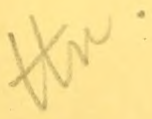


SMITHSONIAN INSTITUTION LIBRARIES
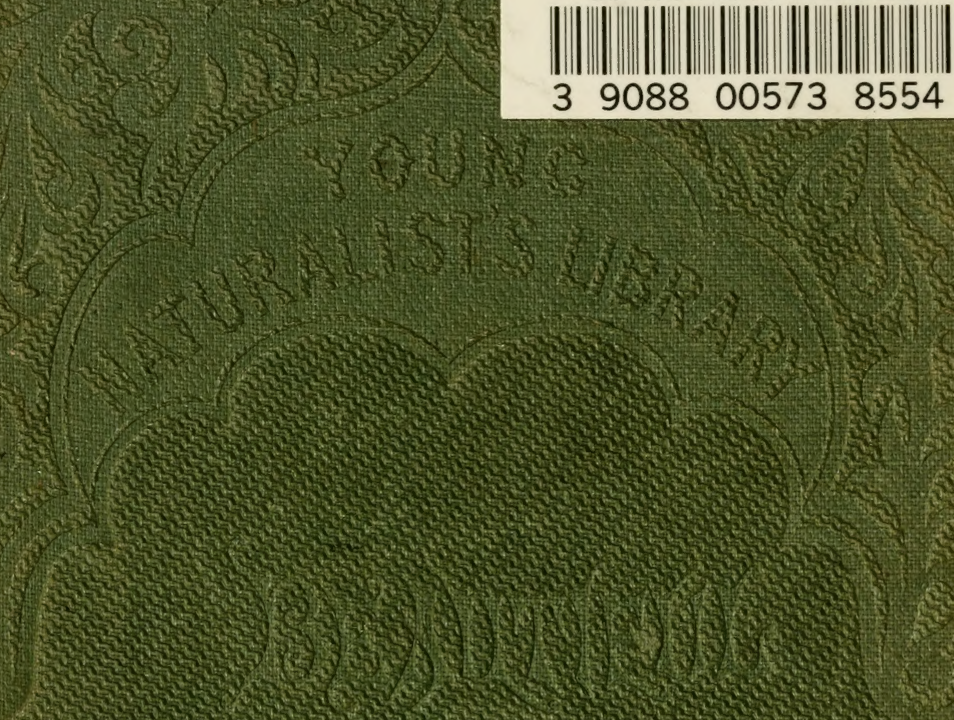